\title{
Article \\ Effects of Application of Pig Manure on the Accumulation of Heavy Metals in Rice
}

\author{
Wenchong Lan ${ }^{1}$, Chunxia Yao ${ }^{2, *}$, Fan Luo ${ }^{1}$, Zhi Jin ${ }^{1}$, Siwen Lu ${ }^{1}$, Jun Li $^{1}$, Xindong Wang ${ }^{1}$ and Xuefeng Hu ${ }^{1, *}$ \\ 1 School of Environmental and Chemical Engineering, Shanghai University, Shanghai 200444, China; \\ lanwenchong@shu.edu.cn (W.L.); fanluo@shu.edu.cn (F.L.); jinzhi@shu.edu.cn (Z.J.); \\ lsw1105@163.com (S.L.); lijun17@shanghai-electric.com (J.L.); 19722709wxd@shu.edu.cn (X.W.) \\ 2 Laboratory of Quality and Safety Risk Assessment for Agro-Products (Shanghai), \\ China Ministry of Agriculture, Institute for Agro-Food Standards and Testing Technology, \\ Shanghai Academy of Agricultural Sciences, Shanghai 201403, China \\ * Correspondence: chunxiayao2007@saas.sh.cn (C.Y.); xfhu@shu.edu.cn (X.H.)
}

check for updates

Citation: Lan, W.; Yao, C.; Luo, F.; Jin, Z.; Lu, S.; Li, J.; Wang, X.; Hu, X. Effects of Application of Pig Manure on the Accumulation of Heavy Metals in Rice. Plants 2022, 11, 207. https://doi.org/10.3390/ plants11020207

Academic Editor: Andrzej Bajguz

Received: 12 December 2021

Accepted: 10 January 2022

Published: 14 January 2022

Publisher's Note: MDPI stays neutral with regard to jurisdictional claims in published maps and institutional affiliations.

Copyright: (C) 2022 by the authors. Licensee MDPI, Basel, Switzerland. This article is an open access article distributed under the terms and conditions of the Creative Commons Attribution (CC BY) license (https:// creativecommons.org/licenses/by/ $4.0 /)$.

\begin{abstract}
Pig manure (PM) is often highly enriched in heavy metals, such as $\mathrm{Cu}$ and $\mathrm{Zn}$, due to the wide use of feed additives. To study the potential risks of heavy metal accumulation in the soil and rice grains by the application of PM and other organic manure, a four-year field experiment was conducted in the suburb of Shanghai, southeast China. The contents of $\mathrm{Cu}, \mathrm{Zn}, \mathrm{Pb}$, and $\mathrm{Cd}$ in the soils and rice plants by the treatments of PM and fungal culturing residues (FCR) show a trend of annual increase. Those in the soils and rice by the PM treatment are raised even more significantly. $\mathrm{Cu}$ and $\mathrm{Zn}$ contents in the soil and rice roots by the PM are significantly higher than those by the non-fertilizer control (CK) during the four years, and $\mathrm{Pb}$ and $\mathrm{Cd}$ also significantly higher than $\mathrm{CK}$ in the latter two years. Heavy metals taken up by the rice plants are mostly retained in the roots. $\mathrm{Cu}$ and $\mathrm{Zn}$ contents in the rice plants are in the decreasing order of roots $>$ grains $>$ stems $>$ leaves, and $\mathrm{Pb}$ and $\mathrm{Cd}$ in the order of roots $>$ stems $>$ leaves $>$ grains. $\mathrm{Cu}, \mathrm{Zn}, \mathrm{Pb}$, and $\mathrm{Cd}$ contents in the soils by the PM treatment increase by $73 \%, 32 \%, 106 \%$, and $127 \%$ on annual average, and those in the brown rice by $104 \%, 98 \%, 275 \%$, and $199 \%$, respectively. The contents of $\mathrm{Cu}, \mathrm{Zn}, \mathrm{Pb}$, and $\mathrm{Cd}$ in the brown rice of the treatments are significantly correlated with those in the soils and rice roots $(p<0.05)$, suggesting the heavy metals accumulated in the rice grains come from the application of PM and FCR. Though the contents of heavy metals in the brown rice during the four experimental years are still within the safe levels, the risks of their accumulative increments, especially by long-term application of PM, can never be neglected.
\end{abstract}

Keywords: pig manure (PM); fungal culturing residues (FCR); rice; heavy metal; soils

\section{Introduction}

Excessive application of chemical fertilizers often leads to agricultural diffuse pollution, causing the eutrophication of surface water and contamination of groundwater [1]. In recent decades, the replacement of chemical fertilizers by organic manure has been highly encouraged in China. The number of live pigs attained 680 million in China in 2016 [2]. PM is not only an important source of organic manure but also a link to the circulation of the livestock-soil-plant system [3]. Long-term application of PM significantly increases the contents of organic matter and nutrients in soils [4].

To prevent pigs from infecting intestinal pathogen and supplement nutrients, some trace elements such as $\mathrm{Cu}, \mathrm{Zn}, \mathrm{Fe}$, and $\mathrm{Mn}$ are often added into livestock feed [5], thus causing the enrichment of heavy metals in the PM [6,7]. According to the investigations, the rates of livestock manures with $\mathrm{Cd}$ and $\mathrm{Pb}$ content exceeding the safe limits of organic fertilizers are $12.3 \%$ and $2.6 \%$, and those with $\mathrm{Cu}$ and $\mathrm{Zn}$ exceeding the limits are $53.9 \%$ and $45.7 \%$, respectively [8]. Long-term application of livestock manures hence often leads to the accumulation of heavy metals in agricultural soils $[9,10]$. PM is particularly 
highly enriched in $\mathrm{Cu}$ and $\mathrm{Zn}$ [11-17]. These in the PM released from an intensively raising farm in China attain as high as $1726 \mathrm{mg} / \mathrm{kg}$ and $1506 \mathrm{mg} / \mathrm{kg}$, respectively [18]. The application of PM often causes the contamination of heavy metals and antibiotics in soils $[19,20]$.

Rice is the staple food of nearly half of the world's population [21]. The rice grain, however, is inclined to accumulate $\mathrm{Cd}$ and other toxic metals, even growing on Cd-low soils. Therefore, it never seldom occurs that $\mathrm{Cd}$ content in the rice in the market exceeds the safe limit $(0.2 \mathrm{mg} / \mathrm{kg})[22,23]$. Whether long-term application of PM influences the contents of $\mathrm{Cd}$ and other toxic heavy metals in rice grains should be paid close attention to.

In this study, a field experiment of application of PM and two FCR are carried out in the suburb of Shanghai for four consecutive years from 2017 to 2020 . The contents of $\mathrm{Cu}$, $\mathrm{Zn}, \mathrm{Pb}$, and $\mathrm{Cd}$ in the soils, rice plants, and grains by the different fertilizer treatments are detected to study the effects of the application of PM and FCR on the accumulation of toxic heavy metals in rice grains and to evaluate its potential edible risks.

\section{Results}

\subsection{Effects of Application of PM and FCR on Soil Nutrients}

\subsubsection{Organic Matter (OM) Content}

The content of OM in the soils by the agaricusbisporus (AB), flammulinavelutipes (FV), and PM treatments shows a trend of annual increase (Figure 1). That in the AB, FV, and PM soils is significantly higher than CK $(p<0.05)$ in each experimental year, which increases by $38.0 \%, 34.2 \%$, and $48.9 \%$ on annual average, respectively. Especially, OM content in the PM soil is significantly higher than that in $\mathrm{AB}, \mathrm{FV}$, and $\mathrm{CK}$.

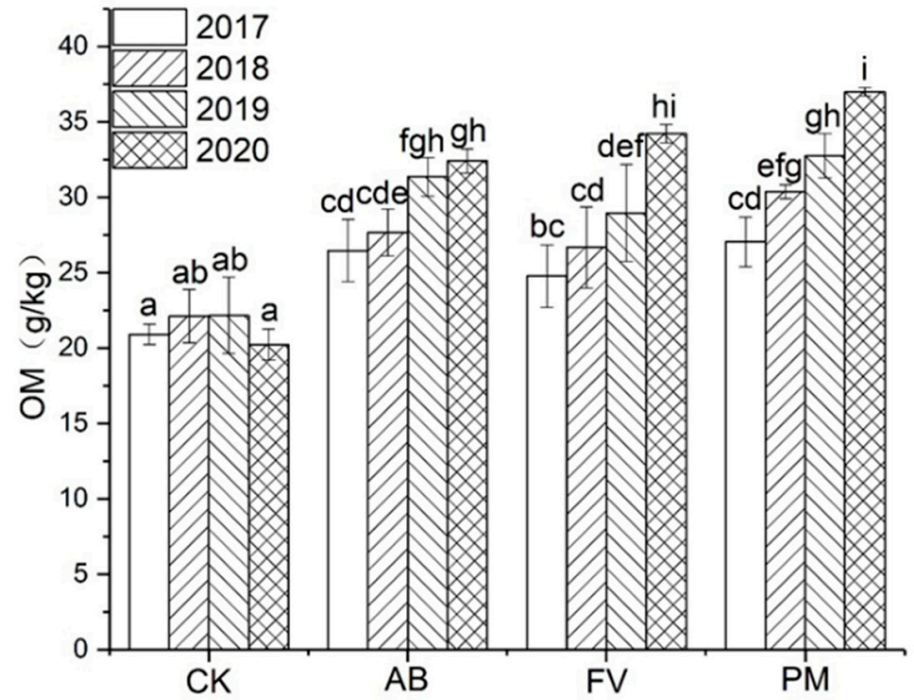

Figure 1. Effects of the different fertilizer treatments on the content of $\mathrm{OM}$ in the soils. All the data are expressed as means $\pm \mathrm{SD} ; n=3$. Different letters on data in the same group indicate a significant difference between them at $p<0.05$ level.

\subsubsection{Total $\mathrm{N}(\mathrm{TN})$ and Alkaline Hydrolyzed $\mathrm{N}(\mathrm{AN})$ Contents}

The contents of TN and $\mathrm{AN}$ in the $\mathrm{AB}, \mathrm{FV}$, and PM soils also increase annually (Figure 2). Compared with $C K$, these in the $\mathrm{AB}$ soil increase by $25.2 \%$ and $23.0 \%$ on annual average during the four experimental years; these in FV increase by $37.7 \%$ and $21.2 \%$; these in PM increase by $36.8 \%$ and $33.8 \%$, respectively. The contents of TN and AN in the PM soil in the fourth year are 1.1 and 1.9 times those in the first year and are higher than those in the AB and FV soils. 

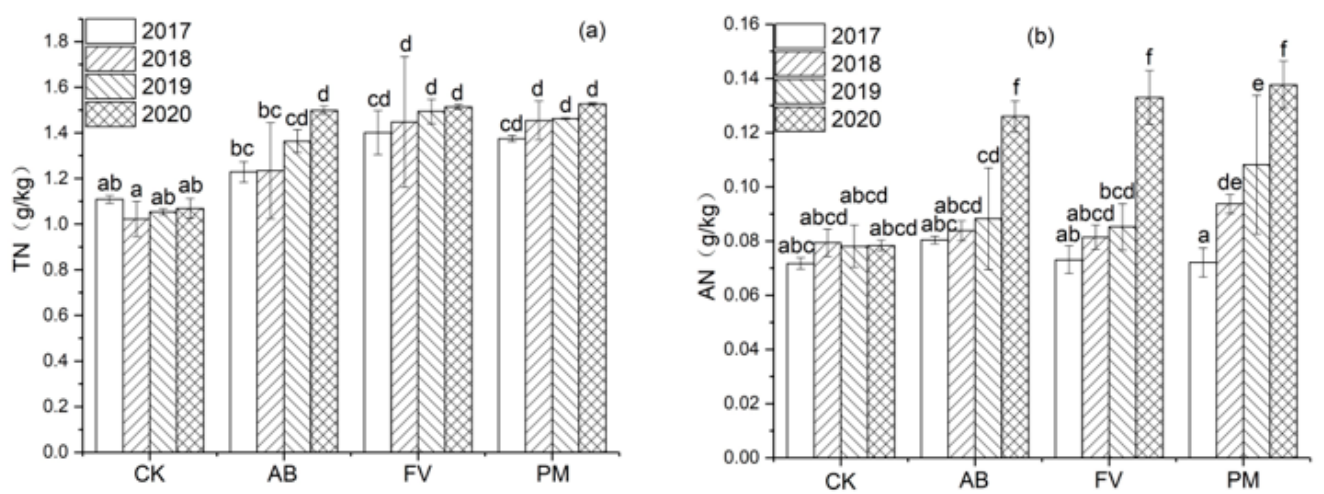

Figure 2. (a) Effects of the different fertilizer treatments on the content of TN in the soils; (b) Effects of the different fertilizer treatments on the content of AN in the soils. All the data are expressed as means $\pm \mathrm{SD} ; n=3$. Different letters on data in the same group indicate a significant difference between them at $p<0.05$ level.

\subsubsection{Total $\mathrm{P}(\mathrm{TP})$ and Available $\mathrm{P}(\mathrm{AP})$ Contents}

The contents of TP and AP in the PM, AB, and FV soils also increase annually (Figure 3 ). Compared with $\mathrm{CK}$, these in the $\mathrm{AB}$ soil increase by $121.6 \%$ and $135.0 \%$ on annual average during the four experimental years; these in the FV soil increase by $109.0 \%$ and $143.2 \%$; these in the PM soil increase by $163.9 \%$ and $254.7 \%$, respectively. TP and AP contents in the PM soil on the fourth year are 2.7 and 3.0 times those on the first year, respectively. The content of AP in the PM soil is significantly higher than that in the AB and FV soils $(p<0.05)$, and TP in the PM soil is also higher than in the AB and FV soils $(p>0.05)$ in the fourth year, suggesting that the PM application is more beneficial to P increase in the soil.
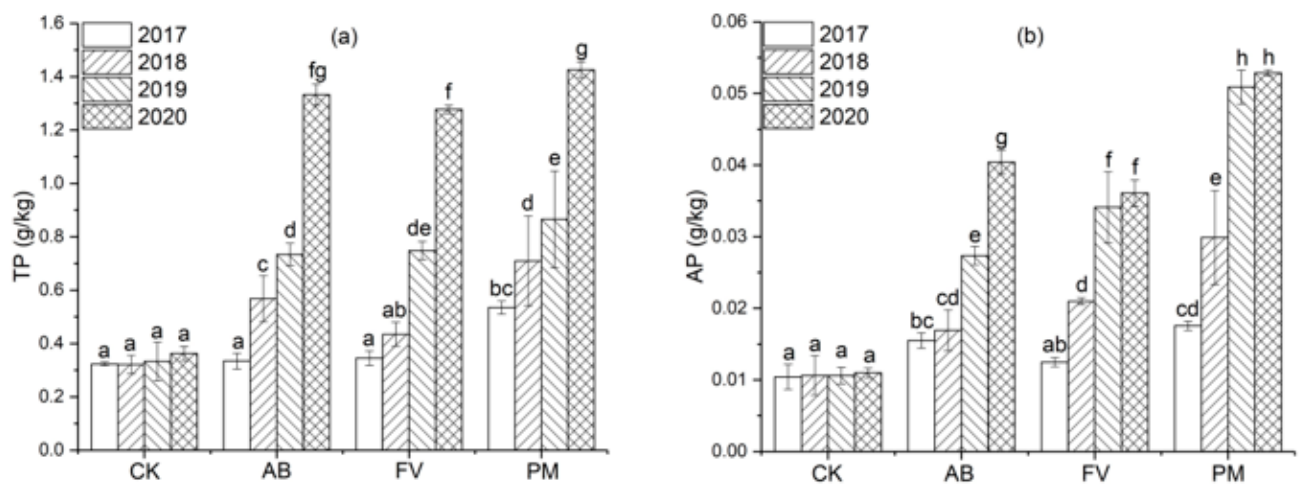

Figure 3. (a) Effects of the different fertilizer treatments on the content of TP in the soils; (b) Effects of the different fertilizer treatments on the content of AP in the soils. Data are expressed as means $\pm S D$; $n=3$. Different letters on data in the same group indicate a significant difference between them at $p<0.05$ level.

\subsubsection{Total K (TK) and Available K (AK) Contents}

The contents of $\mathrm{TK}$ and $\mathrm{AK}$ in the $\mathrm{PM}, \mathrm{AB}$, and FV soils also increase annually (Figure 4). During the four experimental years, the contents of TK and AK in the PM, $\mathrm{AB}$, and FV soils are significantly higher than $\mathrm{CK}(p<0.05)$. Compared with $\mathrm{CK}$, moreover, these in the $\mathrm{AB}$ soil increase by $37.1 \%$ and $93.0 \%$ on annual average; these in the FV soil increase by $49.2 \%$ and $60.6 \%$; these in the PM soil increase by $62.3 \%$ and $93.6 \%$, respectively. TK and AK contents in the PM soil in the fourth year are 1.6 and 1.7 times those in the first year, respectively. The content of AK in the PM soil in the third and fourth years is significantly higher than that in the AB and FV soils $(p<0.05)$. 

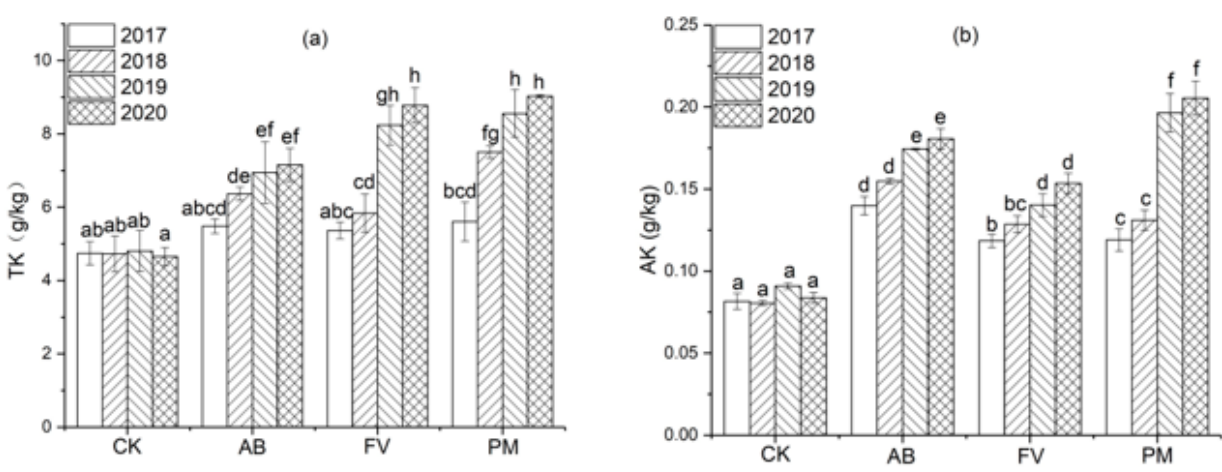

Figure 4. (a) Effects of the different fertilizer treatments on the content of TK in the soils; (b) Effects of the different fertilizer treatments on the content of AK in the soils. Data are expressed as means \pm SD; $n=3$. Different letters on data in the same group indicate a significant difference between them at $p<0.05$ level.

\subsection{Effects of Application of PM and FCR on Rice Yield}

During the four experimental years, the yield of rice grain by the $\mathrm{AB}, \mathrm{FV}$, and $\mathrm{PM}$ treatments increases by $40.0 \%, 45.1 \%$, and $49.8 \%$ on annual average, respectively (Figure 5). The effect of yield increase by the PM treatment is significantly higher than that of $A B$ and FV. The grain yield of the three fertilizer treatments in the second and third years is significantly higher than that of the first year $(p<0.05)$. That of the fourth year, however, is significantly reduced, possibly related to unsuitable climate and severer incidence of rice pests and diseases.

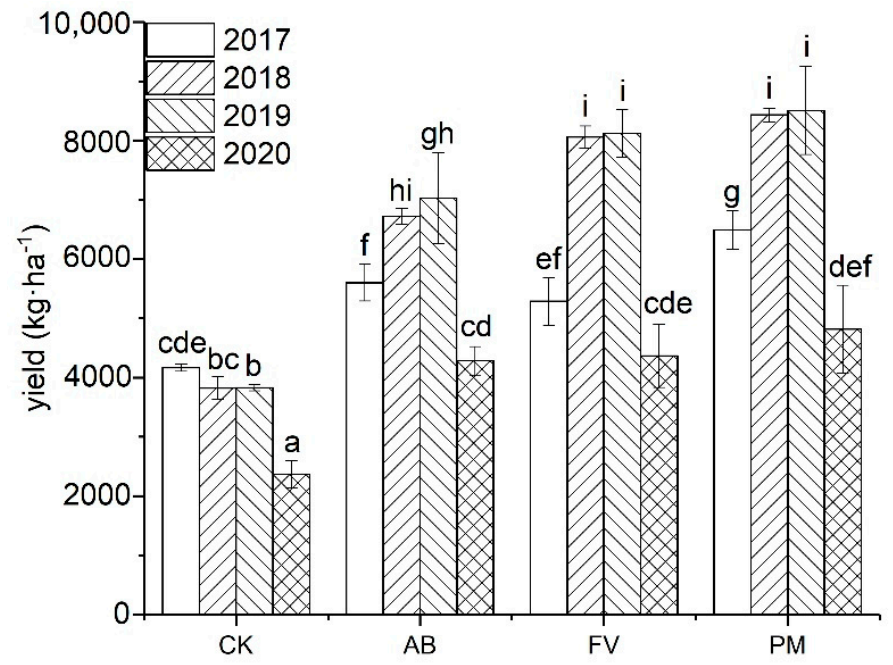

Figure 5. Yield of rice grains by the different fertilizer treatments during the four experimental years. Data are expressed as means $\pm \mathrm{SD} ; n=3$. Different letters on data in the same group indicate a significant difference between them at $p<0.05$ level.

\subsection{Effects of Application of PM and FCR on the Accumulation of Heavy Metals in the Soil} Plant System

\subsubsection{Heavy Metal Contents in the Soils}

During the four experimental years, the contents of $\mathrm{Cu}, \mathrm{Zn}, \mathrm{Pb}$, and $\mathrm{Cd}$ in the $\mathrm{PM}$, $\mathrm{AB}$, and $\mathrm{FV}$ soils also show a trend of annual increase, which are mostly higher than $\mathrm{CK}$ (Figure 6). Especially, the contents of $\mathrm{Cu}$ and $\mathrm{Zn}$ in the PM soil during the four years are significantly higher than $\mathrm{CK}(p<0.05)$ (Figure $6 \mathrm{a}, \mathrm{b})$, and $\mathrm{Pb}$ and $\mathrm{Cd}$ in the latter two years are also significantly higher than CK $(p<0.05)$ (Figure $6 c, d)$. 

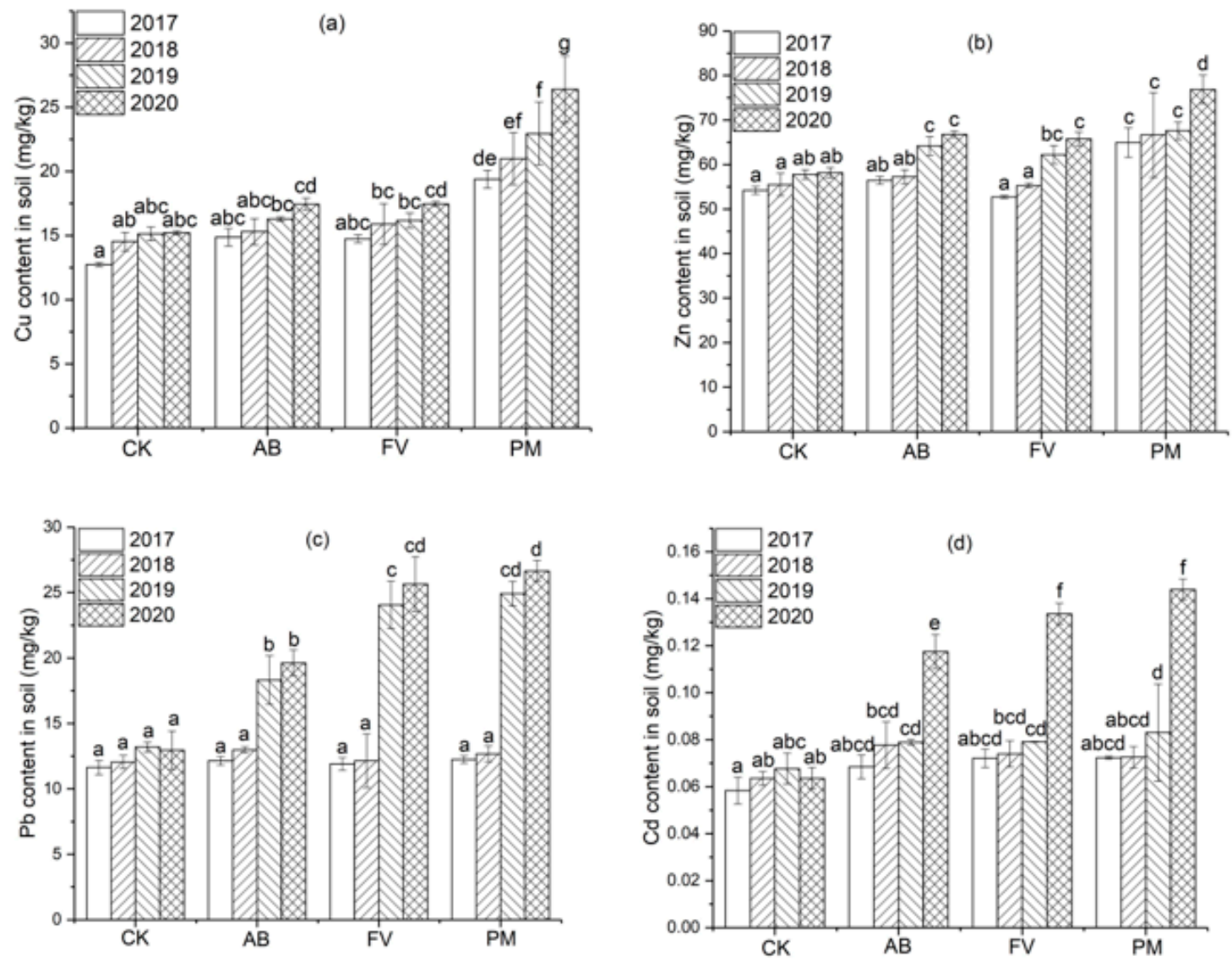

Figure 6. (a) $\mathrm{Cu}$ content in the soils by the different fertilizer treatments during the four experimental years; (b) Zn content in the soils by the different fertilizer treatments during the four experimental years; (c) Pb content in the soils by the different fertilizer treatments during the four experimental years; (d) Cd content in the soils by the different fertilizer treatments during the four experimental years. Data are expressed as means $\pm \mathrm{SD} ; n=3$. Different letters on data in the same group indicate a significant difference between them at $p<0.05$ level.

During the four years from 2017 to 2020, $\mathrm{Cu}$ content in the PM soils is 1.5, 1.4, 1.5, and 1.7 times higher than CK (Figure 6a), and $\mathrm{Zn}$ content is 1.2, 1.2, 1.2, and 1.3 times higher than $\mathrm{CK}$ (Figure 6b), respectively. Pb content in the PM soil in the latter two years is 1.9 and 2.1 times higher than CK (Figure 6c), and Cd content is 1.2 and 2.3 times higher than CK (Figure 6d), respectively.

\subsubsection{Heavy Metal Contents in the Rice Roots}

The contents of $\mathrm{Cu}, \mathrm{Zn}, \mathrm{Pb}$, and $\mathrm{Cd}$ in the rice roots of the $\mathrm{PM}, \mathrm{AB}$, and $\mathrm{FV}$ treatments all show an annual increasing trend and attain maximum values in the fourth year (Figure 7).

$\mathrm{Cu}$ content in the rice roots of the $\mathrm{PM}, \mathrm{AB}$, and FV treatments in the fourth year is mostly significantly higher than that in the earlier three years $(p<0.05)$ (Figure 7a). Especially, that of PM on the fourth year attains $22.82 \mathrm{mg} / \mathrm{kg}$, which is $2.9,1.5$, and 1.1 times higher than that of $\mathrm{CK}, \mathrm{AB}$, and FV in the same year, respectively. During the four experimental years, the $\mathrm{Cu}$ content of the PM roots is significantly higher than that of $\mathrm{CK}$ and $\mathrm{AB}(p<0.05)$. Meanwhile, $\mathrm{Zn}$ content in the rice roots of the three treatments in the latter three years is significantly higher than that in the first year $(p<0.05)$ (Figure $7 \mathrm{~b})$. That in the PM roots in the latter two years is significantly higher than in the first two years $(p<0.05)$. Zn content in the PM roots is significantly higher than that in $\mathrm{CK}, \mathrm{AB}$, and FV $(p<0.05)$ during the four years. That on the fourth year attains as high as $62.84 \mathrm{mg} / \mathrm{kg}$, which is 3.0, 1.6, and 1.6 times higher than in $\mathrm{CK}, \mathrm{AB}$, and $\mathrm{FV}$, respectively. Pb content in the PM roots in the latter two years is significantly higher than that in $\mathrm{CK}$ and $\mathrm{AB}(p<0.05)$ 
(Figure 7c). That on the fourth year attains $9.33 \mathrm{mg} / \mathrm{kg}$, which is 2.0, 1.3, and 1.1 times higher than that of $\mathrm{CK}, \mathrm{AB}$, and $\mathrm{FV}$, respectively. $\mathrm{Cd}$ content in the PM roots during the four experimental years is higher than that of CK, AB, and FV (Figure 7d). That on the fourth year attains $1.48 \mathrm{mg} / \mathrm{kg}$, which is 2.7 times higher than CK and 3.5 times higher than in the first year.
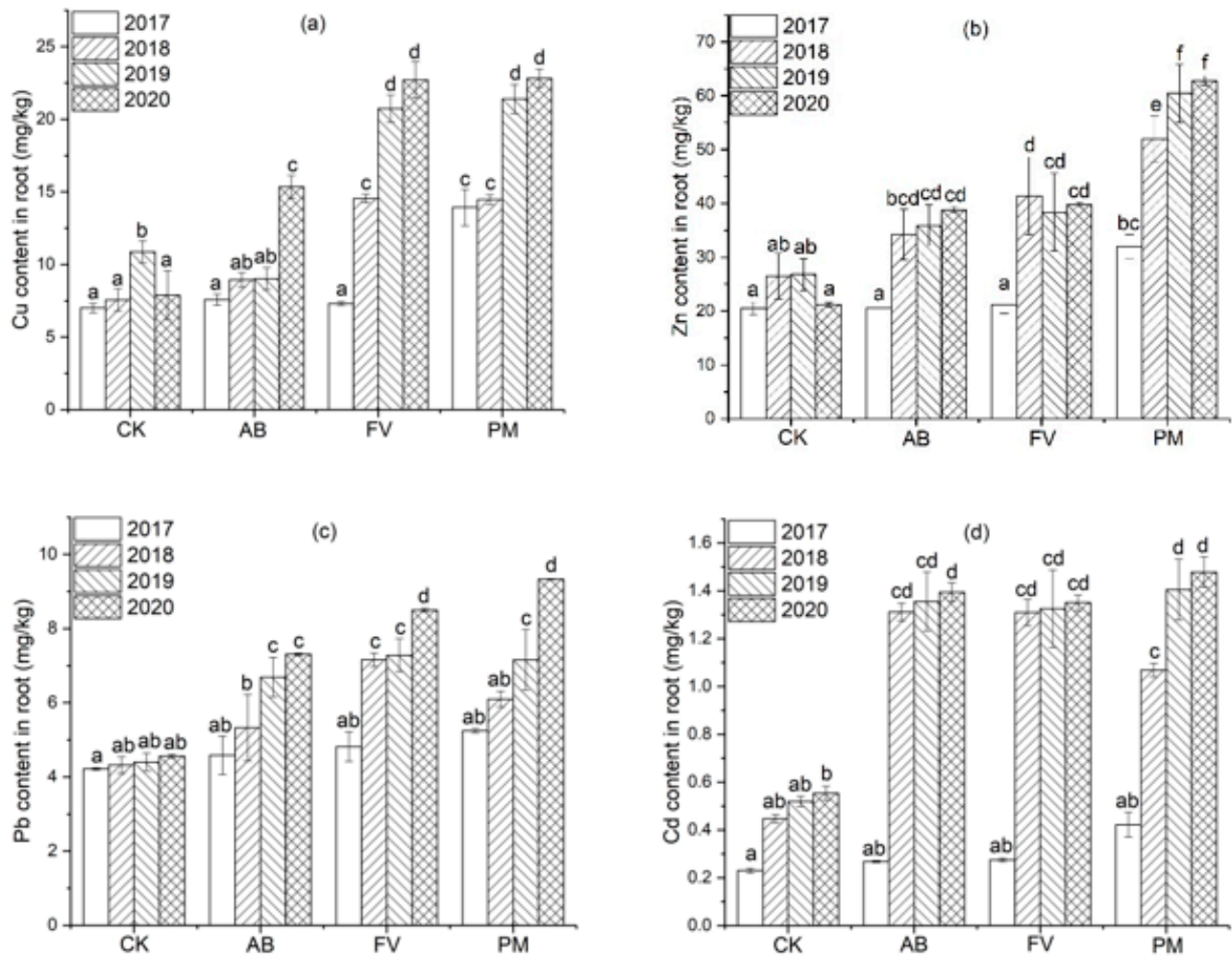

Figure 7. (a) $\mathrm{Cu}$ content in the rice roots by the different fertilizer treatments during the four experimental years; (b) Zn content in the rice roots by the different fertilizer treatments during the four experimental years; (c) $\mathrm{Pb}$ content in the rice roots by the different fertilizer treatments during the four experimental years; (d) Cd content in the rice roots by the different fertilizer treatments during the four experimental years. Data are expressed as means $\pm \mathrm{SD} ; n=3$. Different letters on data in the same group indicate a significant difference between them at $p<0.05$ level.

\subsubsection{Heavy Metal Content in the Rice Grains}

The contents of $\mathrm{Cu}, \mathrm{Zn}, \mathrm{Pb}$, and $\mathrm{Cd}$ in the brown rice of the three treatments also show a trend of annual increase, correlated with the annual increase in heavy metals in the soils and rice roots. Especially, these of PM during the four years are mostly significantly higher than CK $(p<0.05)$, and also mostly higher than these of AB and FV (Figure 8).

$\mathrm{Cu}$ content in the brown rice of PM is enhanced even more significantly and increases by $14.9 \%, 74.4 \%, 80.7 \%$, and $103.6 \%$ annuallyduring the four years, compared with $\mathrm{CK}$; that of $\mathrm{AB}$ increases by $7.5 \%, 20.6 \%, 77.3 \%$, and $80.0 \%$; that of FV increases by $11.3 \%, 51.4 \%$, $71.2 \%$, and $73.7 \%$, respectively (Figure $8 \mathrm{a}$ ). Zn content in the brown rice of PM increases by $12.9 \%, 37.8 \%, 46.1 \%$, and $97.5 \%$; that of the $\mathrm{AB}$ by $5.2 \%, 24.1 \%, 42.8 \%$, and $45.3 \%$; that of the FV by $3.6 \%, 25.5 \%, 30.2 \%$, and $71.8 \%$, respectively (Figure $8 \mathrm{~b}$ ).Pb content in the brown rice of the PM increases by $16.0 \%, 9.2 \%, 4.6 \%$, and $274.9 \%$; that of $\mathrm{AB}$ increases by $6.0 \%$, $10.2 \%, 14.0 \%$ and $128.3 \%$; that of FV increases by $9.2 \%, 5.4 \%, 17.3 \%$, and $134.3 \%$, respectively (Figure 8c). Cd content of the brown rice of PM increases by $28.5 \%, 112.8 \%, 147.8 \%$, and $198.9 \%$; that of $\mathrm{AB}$ increases by $7.3 \%, 71.2 \%, 84.7 \%$, and $155.4 \%$; that of FV increases by $35.2 \%, 62.8 \%, 92.2 \%$, and $140.7 \%$, respectively (Figure $8 d$ ). 

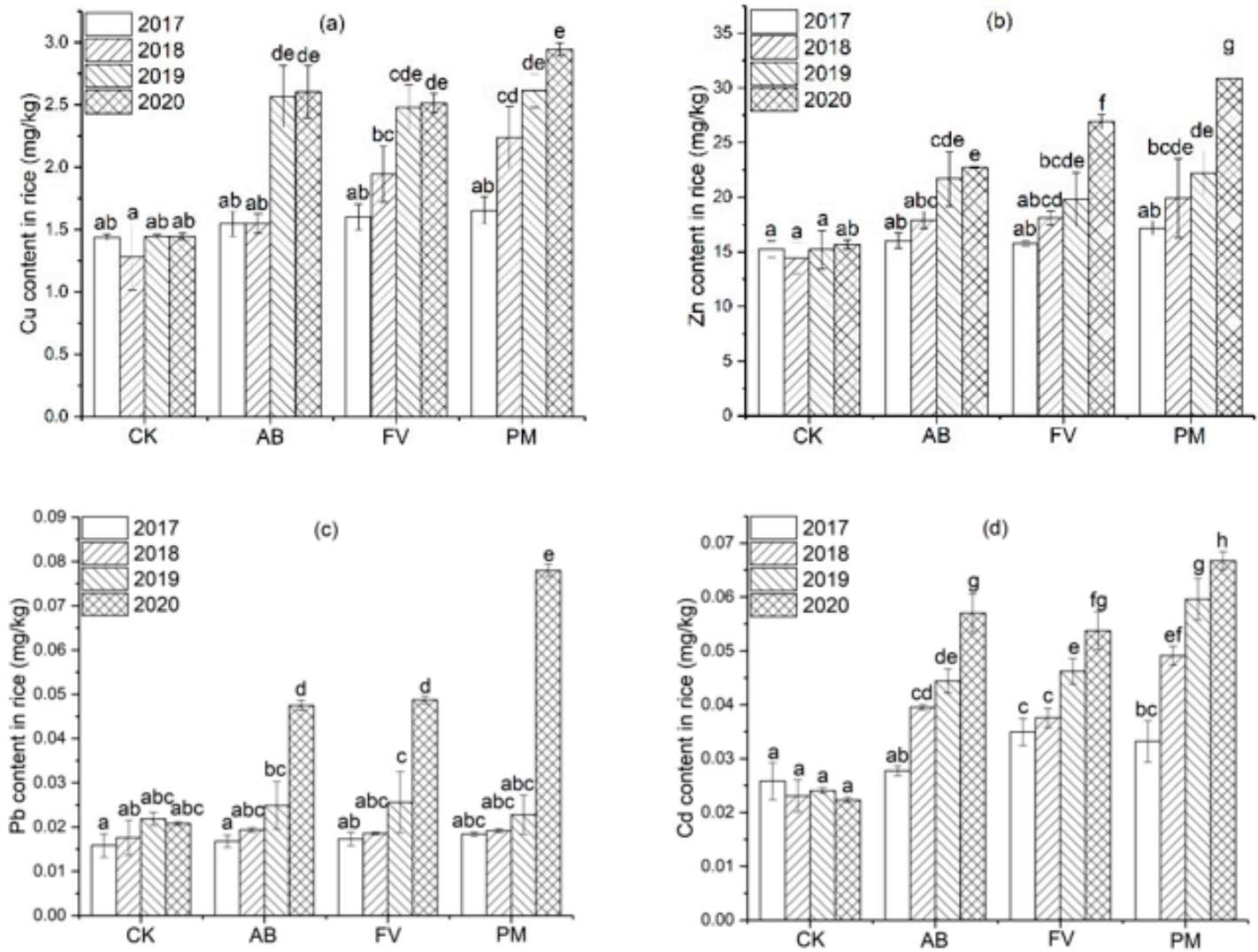

Figure 8. (a) $\mathrm{Cu}$ content in the brown rice by the different fertilizer treatments during the four experimental years; (b) Zn content in the brown rice by the different fertilizer treatments during the four experimental years; (c) $\mathrm{Pb}$ content in the brown rice by the different fertilizer treatments during the four experimental years; (d) Cd content in the brown rice by the different fertilizer treatments during the four experimental years. Data are expressed as means $\pm \mathrm{SD} ; n=3$. Different letters on data in the same group indicate a significant difference between them at $p<0.05$ level.

\subsubsection{Distribution of Heavy Metals in the Rice Plants}

The distribution of $\mathrm{Cu}, \mathrm{Zn}, \mathrm{Pb}$, and $\mathrm{Cd}$ in the different tissues of rice plants by the three treatments on the fourth year shows a similar rule (Figure 9): $\mathrm{Cu}$ content in the rice roots is significantly higher than that in the rice stems, leaves and brown rice $(p<0.05)$ (Figure 9a). Especially, $\mathrm{Cu}$ in the rice roots of PM is 11.5, 15.1, and 7.7 times that in the rice stems, leaves, and brown rice, respectively. Moreover, $\mathrm{Cu}$ content in brown rice is higher than that in rice stems and leaves $(p<0.05)$. Zn content in the rice roots and brown rice is also higher than that in the stems and leaves (Figure 9b). Especially, that of PM attains 62.84 and $30.90 \mathrm{mg} / \mathrm{kg}$, respectively, which is significantly higher than in the stems and leaves $(p<0.05)$.

$\mathrm{Pb}$ content in the rice roots is significantly higher than that in the stems, leaves, and brown rice $(p<0.05)$, while that in the stems is also significantly higher than in the leaves and rice $(p<0.05)$ (Figure $9 c)$. Cd content in the different tissue of rice plants shares a similar distribution with $\mathrm{Pb}$ (Figure 9d). 

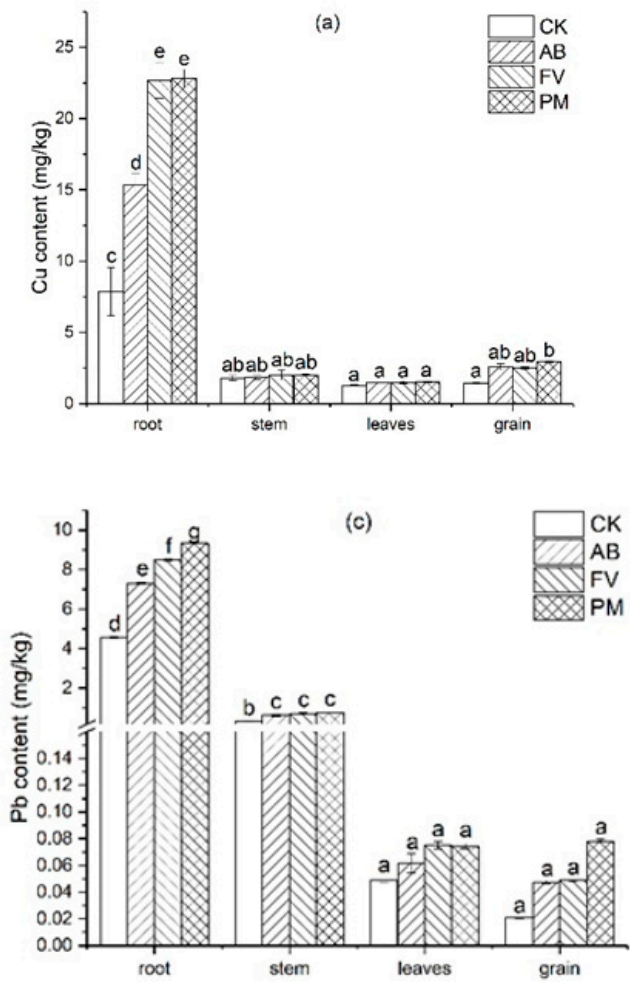
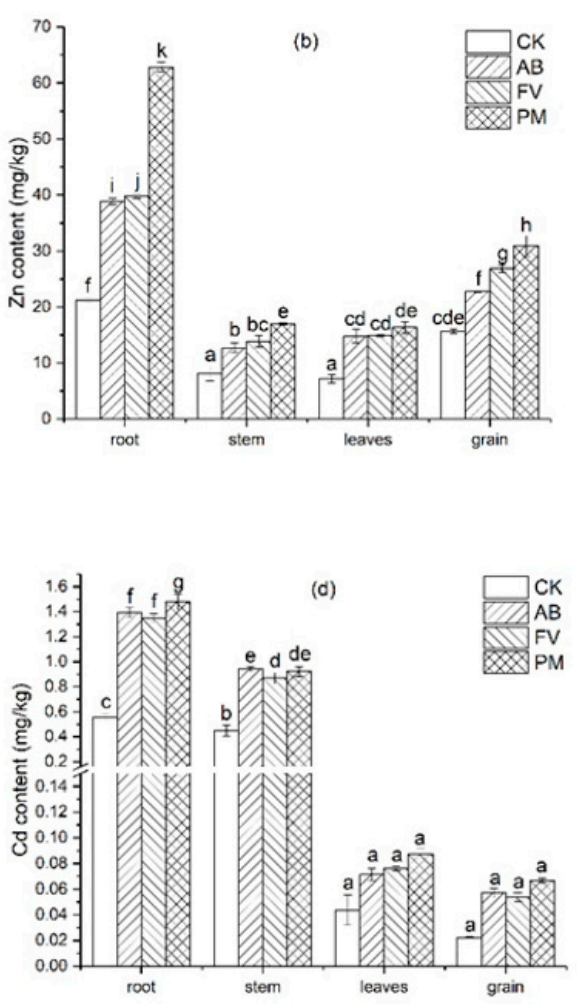

Figure 9. (a) Distribution of $\mathrm{Cu}$ content in the rice plants on the fourth experimental year; (b) distribution of $\mathrm{Zn}$ content in the rice plants on the fourth experimental year; (c) distribution of $\mathrm{Pb}$ content in the rice plants on the fourth experimental year; (d) distribution of $\mathrm{Cd}$ content in the rice plants on the fourth experimental year. Data are expressed as means $\pm \mathrm{SD} ; n=3$. Different letters on data in the same group indicate a significant difference between them at $p<0.05$ level.

\section{Discussion}

\subsection{Enhancements of Soil Nutrients by Application of PM and FCR}

Soil fertility is gradually improved after the application of PM and FCR. The content of $\mathrm{OM}$ in the soils of $\mathrm{AB}, \mathrm{FV}$ and PM increases by $38.0 \%, 34.2 \%$, and $48.9 \%$ on annual average during the four years; $\mathrm{TN}, 25.1 \%, 38.4 \%$, and $37.1 \%$; $\mathrm{AN}, 23.0 \%, 21.2 \%$, and $33.8 \%$; $\mathrm{TP}, 121.6 \%, 109.4 \%$, and $163.9 \%$; AP, $135.0 \%, 143.2 \%$, and $254.7 \%$; TK, $37.1 \%, 49.2 \%$, and $62.3 \%$; AK 93.0\%, 60.6\%, and 93.6\%, respectively. During the four experimental years, the content of OM in the soils of PM is significantly higher than that of $A B, F V$, and $C K$ (Figure 1). The application of PM and FCR increases the content of soil OM and improves soil quality significantly [24,25]. The effects of PM application on the improvement of soil fertility are even more significant [26]. The excessive application of PM, however, often causes the accumulation of $\mathrm{P}$ in soils (Figure 3) and increases the risk of agricultural diffuse pollution [27].

Correlating with the annual enhancement of soil nutrients, the yield of rice grain of $\mathrm{AB}$, $\mathrm{FV}$, and PM increases by $40.0 \%, 45.1 \%$, and $49.8 \%$, on annual average, respectively. There is a significant positive correlation between the content of $\mathrm{OM}$ in the soils and the yield of rice grains $(\mathrm{r}=0.886, n=12 ; p<0.01)$, further suggesting that the application of organic manure has contributed to the yield increase. The effects of yield increase by PM are even more significant as PM contains high content of nutrients [28,29]. Moreover, higher content of $\mathrm{Zn}$ in PM may also contribute to yield increase [30,31]. Over the first three years, the grain yield by the AB, FV, and PM continuously increases, and that of PM is significantly higher than of $\mathrm{AB}$ and $\mathrm{FV}$, which is consistent with the previous results [32-34]. In the fourth year, the yield of rice grain of the treatments, however, is significantly reduced (Figure 5), which may be related to the unsuitable climatic conditions and high incidences of rice pests and diseases this year. 


\subsection{Accumulation of Heavy Metals in the Soils Caused by Application of PM and FCR}

Feed additives commonly used in pig breeding often contain a certain amount of heavy metals, such as $\mathrm{Cu}, \mathrm{Zn}, \mathrm{Fe}$, and $\mathrm{Mn}$, which are used to prevent diseases, supplement nutrients and improve the growth of pigs [35-37]. The heavy metals added into feed are finally mostly released with dung $[37,38]$. PM is thus often highly enriched in $\mathrm{Cu}$ and $\mathrm{Zn}[39,40]$ and sometimes even contains toxic metals or metalloids such as $\mathrm{Cd}$ and As [41,42]. Toxic heavy metals in organic fertilizers that are made from animal manures therefore often exceed the safe limits [43]. The contents of $\mathrm{Cu}$ and $\mathrm{Zn}$ in 117 samples of organic fertilizers in northern China are $75.2 \mathrm{mg} / \mathrm{kg}$ and $581.9 \mathrm{mg} / \mathrm{kg}$ on average, respectively [44]. Cu content in the PM used in this study is 5.5 and 20.8 times that of FV and $\mathrm{AB}$, and $\mathrm{Zn}$ content 4.4 and 16.3 times that of $\mathrm{FV}$ and $\mathrm{AB}$, respectively (Table 1 . The contents of $\mathrm{Pb}$ and $\mathrm{Cd}$ in the PM are also significantly higher than those in the two FCR $(p<0.05)$ (Table 1).

Table 1. Nutrient and heavy metal content of PM and FCR in field experiments. Data are means \pm SD, $n=3$. Different letters indicate significant differences between treatments at $p<0.05$ according to the Duncan test.

\begin{tabular}{|c|c|c|c|c|c|c|c|c|c|c|}
\hline Organic Fertilizer & pH & OM (\%) & Water Content $(\%)$ & $\mathrm{TN}(\mathrm{g} / \mathrm{kg})$ & TP (g/kg) & TK (g/kg) & $\mathrm{Cu}(\mathrm{mg} / \mathrm{kg})$ & $\mathrm{Zn}(\mathrm{mg} / \mathrm{kg})$ & $\mathrm{Pb}(\mathrm{mg} / \mathrm{kg})$ & $\mathrm{Cd}(\mathrm{mg} / \mathrm{kg})$ \\
\hline FV & $5.50 \pm 0.11$ & $71.75 \pm 0.89$ & $77.66 \pm 0.13$ & $20.34 \pm 0.26$ & $10.20 \pm 0.09$ & $3.07 \pm 0.07$ & $8.00 \pm 0.81 c$ & $33.46 \pm 5.95 c$ & $0.52 \pm 0.16 \mathrm{c}$ & $0.15 \pm 0.05 c$ \\
\hline $\mathrm{AB}$ & $5.85 \pm 0.16$ & $36.49 \pm 0.63$ & $75.63 \pm 0.12$ & $19.24 \pm 0.31$ & $4.36 \pm 0.05$ & $2.65 \pm 0.15$ & $30.09 \pm 0.49 \mathrm{~b}$ & $123.72 \pm 6.52 b$ & $1.71 \pm 0.43 \mathrm{~b}$ & $0.30 \pm 0.05 \mathrm{~b}$ \\
\hline PM & $6.99 \pm 0.19$ & $33.81 \pm 0.55$ & $12.04 \pm 0.15$ & $21.05 \pm 0.18$ & $15.43 \pm 0.16$ & $3.76 \pm 0.21$ & $166.76 \pm 19.99 a$ & $544.74 \pm 75.48 \mathrm{a}$ & $3.20 \pm 0.14 \mathrm{a}$ & $0.43 \pm 0.03 a$ \\
\hline
\end{tabular}

The inputs of heavy metals into the soils through the application of PM and FCR are much higher than the outputs by the uptake of rice plants, resulting in the annual increase in $\mathrm{Cu}, \mathrm{Zn}, \mathrm{Pb}$, and $\mathrm{Cd}$ contents in the soils for the consecutive four years (Figure 10). The contents of $\mathrm{Cu}$ and $\mathrm{Zn}$ in the PM soil are significantly higher than CK $(p<0.05)$ during the four years, and the contents of $\mathrm{Pb}$ and $\mathrm{Cd}$ in the $\mathrm{PM}$ soil are also significantly higher than $\mathrm{CK}(p<0.05)$ in the latter two years. The contents of $\mathrm{Zn}$ and $\mathrm{Pb}$ in the AB and FV soils are significantly higher than $\mathrm{CK}(p<0.05)$ in the latter two years, and Cd content in the AB and FV soils is also significantly higher than CK $(p<0.05)$ on the fourth years, which is, however, still much lower than in the PM soil (Figure 6). This suggests that the contents of heavy metals in the soils are significantly raised by the application of PM and FCR, and those by the application of PM are more significant. $\mathrm{Cu}$ content in the soils of PM annually increases by $8.3 \%, 9.3 \%$, and $15.0 \%$; $\mathrm{Zn}$ content by $2.6 \%, 1.4 \%$, and $13.7 \%$; $\mathrm{Pb}$ content by $3.5 \%, 96.5 \%$, and $7.0 \%$; Cd content by $0.4 \%, 14.4 \%$, and $73.3 \%$, respectively.

$\mathrm{Pb}$ and $\mathrm{Cd}$ are even more rapidly accumulated in the soils than $\mathrm{Cu}$ and $\mathrm{Zn}$. The contents of $\mathrm{Pb}$ and $\mathrm{Cd}$ in the PM soil in the fourth year are 2.2 and 2.0 times that on the first year, while $\mathrm{Cu}$ and $\mathrm{Zn}$ in the fourth year are 1.4 and 1.2 times that on the first year (Figure 10). It may be because both $\mathrm{Cu}$ and $\mathrm{Zn}$ are nutrient elements and highly taken up by crops, while $\mathrm{Cd}$ and $\mathrm{Pb}$ are toxic to and less assimilated by crops and thus are mostly adsorbed by soil particles. Cd is easily accumulated in soil by fertilizer application [45]. $\mathrm{Cd}$ in the cultivated layers of soil is significantly raised after the application of PM for 10 years [42,46]. The high content of P in PM may also contribute to the accumulation of toxic metals in the soil as the combination of $\mathrm{P}$ with $\mathrm{Cd}$ and $\mathrm{Pb}[47,48]$.

The content of $\mathrm{OM}$ in the soils is significantly correlated with that of $\mathrm{Cu}, \mathrm{Zn}, \mathrm{Pb}$, and $\mathrm{Cd}$ in the soils ( $\mathrm{r}=0.856,0.803,0.928,0.973, n=12 ; p<0.01)$, further suggesting that the accumulation of heavy metals in the soils is mainly attributed to the application of organic manure. On the other hand, the high content of OM is beneficial to the accumulation of heavy metals due to the function of chelation [49-52]. The higher the content of OM in the soil is, the more $\mathrm{Cd}$ is accumulated in the soil [53].

The contents of $\mathrm{Cu}$ and $\mathrm{Zn}$ in the PM are over the safe limits of organic fertilizers; $\mathrm{Pb}$ and $\mathrm{C}$ dare below the safe limits $(\mathrm{Cu}<100 ; \mathrm{Zn}<500 ; \mathrm{Cd}<3 ; \mathrm{Pb}<100)$ specified by the China national standards (NY-525-2012) [54]. The risks of heavy metal accumulation caused by the long-term application of PM and FCR can never be neglected. Long-term application of livestock manure, especially PM, is one of the important reasons for the 
accumulation of heavy metals in farmland $[10,25,55,56]$. The application of PM results in the enhancement of $\mathrm{Cu}, \mathrm{Zn}, \mathrm{Pb}$, and $\mathrm{Cd}$ contents in soils [57-59]. In this study, the annual increments of $\mathrm{Cu}, \mathrm{Zn}, \mathrm{Pb}$, and $\mathrm{Cd}$ in the soil are 2.33,3.97, 4.80, and $0.024 \mathrm{mg} / \mathrm{kg}$ on annual average, respectively. According to the rates of increase, the contents of $\mathrm{Cu}, \mathrm{Zn}, \mathrm{Pb}$, and $\mathrm{Cd}$ in the soil will exceed the safe limits $(\mathrm{Cu} \leq 100 \mathrm{mg} / \mathrm{kg} ; \mathrm{Zn} \leq 250 \mathrm{mg} / \mathrm{kg} ; \mathrm{Pb} \leq 140 \mathrm{mg} / \mathrm{kg}$; $\mathrm{Cd} \leq 0.60 \mathrm{mg} / \mathrm{kg}$ ) according to the China national standards (GB15618-2018) [60] after the application of PM for 35, 47, 27, and 22 years.
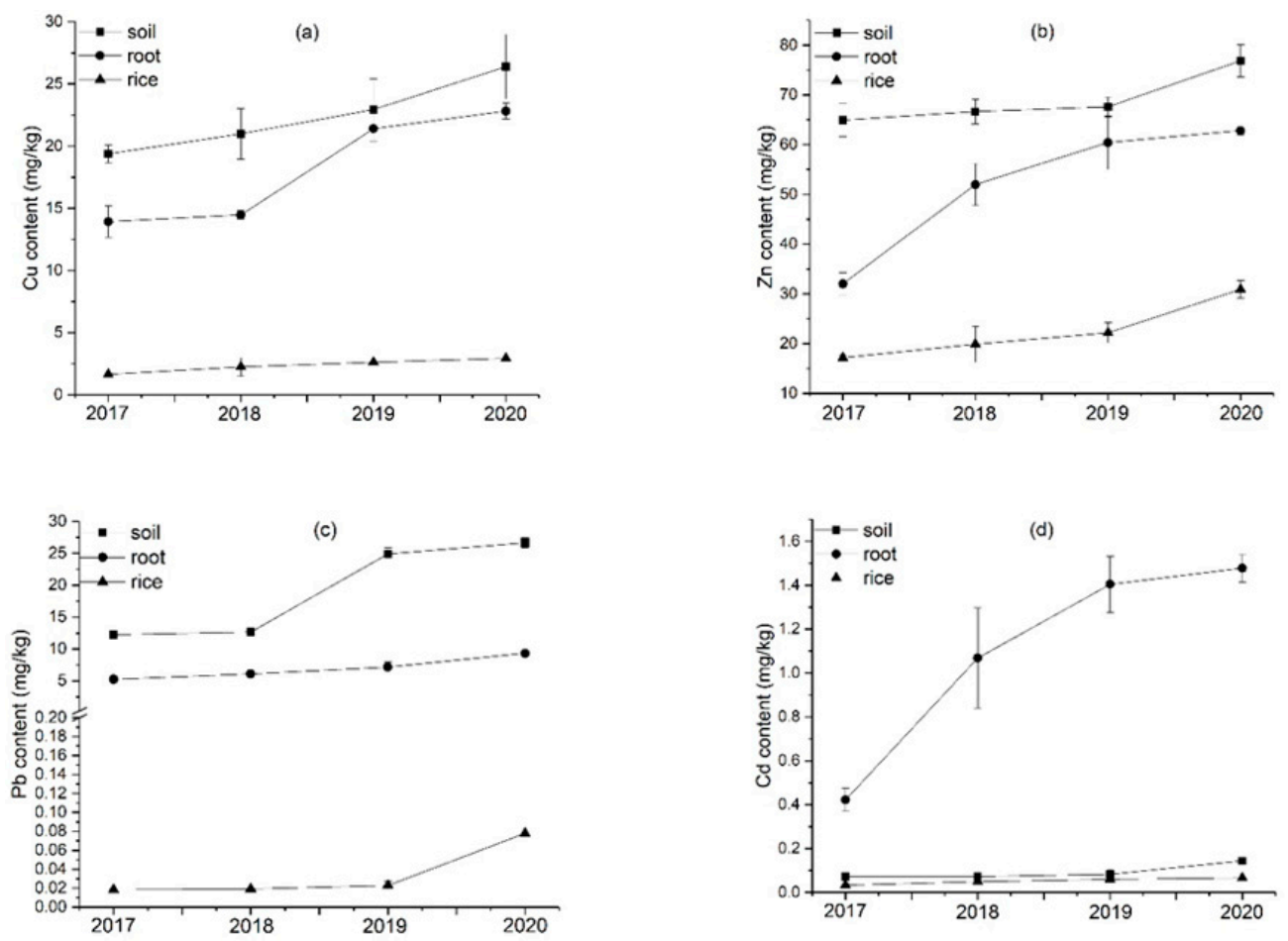

Figure 10. (a) Annual increasing rates of $\mathrm{Cu}$ content in the soils, rice roots, and brown rice by the application of PM during the four experimental years; (b) annual increasing rates of Zn content in the soils, rice roots, and brown rice by the application of PM during the four experimental years; (c) annual increasing rates of $\mathrm{Pb}$ content in the soils, rice roots and brown rice by the application of PM during the four experimental years; (d) annual increasing rates of $\mathrm{Cd}$ content in the soils, rice roots, and brown rice by the application of PM during the four experimental years. Data are expressed as means $\pm \mathrm{SD} ; n=3$.

\subsection{Distribution of Heavy Metals in Rice Plants}

Roots are the passageway of heavy metals from the soil into crops. The contents of $\mathrm{Cu}$ $\mathrm{Zn}, \mathrm{Pb}$, and $\mathrm{Cd}$ in the rice roots are significantly positively correlated with those in the soils in each experimental year $(\mathrm{r}=0.723,0.707,0.983,0.944, n=12 ; p<0.05)$, also suggesting that the enhancement of heavy metals in the rice roots is caused by their accumulation in the soils. The contents of $\mathrm{Cu}, \mathrm{Zn}, \mathrm{Pb}$, and $\mathrm{Cd}$ in the rice roots of the three treatments show an annual cumulative trend (Figure 9). The contents of $\mathrm{Cu}$ and $\mathrm{Zn}$ in the rice roots of PM are significantly higher than $\mathrm{CK}(p<0.05)$ during the four years, the content of $\mathrm{Pb}$ in the PM rice roots is significantly higher than CK $(p<0.05)$ in the latter two years, and Cd in the PM rice roots is significantly higher than $\mathrm{CK}(p<0.05)$ in the latter three years. $\mathrm{Cu}$ content in the $\mathrm{AB}$ rice roots is significantly higher than $\mathrm{CK}(p<0.05)$ in the fourth year, and that in the FV rice roots is significantly higher than CK $(p<0.05)$ in the latter two years. The content of $\mathrm{Zn}$ in the rice roots of $\mathrm{AB}$ and $\mathrm{FV}$ is significantly higher than $\mathrm{CK}(p<0.05)$ in the latter three years, $\mathrm{Pb}$ content in the rice roots of $\mathrm{AB}$ and FV is significantly higher than $\mathrm{CK}(p<0.05)$ in the latter two years, and $\mathrm{Cd}$ in the $\mathrm{AB}$ and FV roots is also significantly higher than $\mathrm{CK}(p<0.05)$ in the latter two years (see Figure 7). The contents of heavy metals in the roots of AB and FV, however, are still much lower than those of PM, also suggesting that the application of PM 
and FCR have made heavy metals accumulate in the rice roots, and the accumulation by the $\mathrm{PM}$ is even more significant. $\mathrm{Cu}$ content in the rice roots of PM annually increases by 3.8\%, $47.9 \%$ and $6.7 \%$ from 2018 to 2020 ; $\mathrm{Zn}$ by $62.3 \%, 16.2 \%$, and $4.0 \%$; $\mathrm{Pb}$ by $16.3 \%, 17.4 \%$ and $30.4 \%$; Cd by $153.1 \%, 31.4 \%$ and $5.2 \%$, respectively (Figure 7). Especially, Cd content in the rice roots of PM on the fourth year attains as high as $1.48 \mathrm{mg} / \mathrm{kg}$, which is 3.5 times that on the first year and also one order magnitude that in the soils. This suggests that $\mathrm{Cd}$ can be actively taken up by the rice roots from the soils.

Heavy metals taken up by the rice roots are partially translocated to the aerial parts. The contents of $\mathrm{Cu}, \mathrm{Zn}, \mathrm{Pb}$, and $\mathrm{Cd}$ in the aerial parts of the rice plants of $\mathrm{PM}$ in the fourth year are $22.0 \%, 50.5 \%, 8.9 \%$, and $42.2 \%$ of the total, respectively. Both $\mathrm{Cu}$ and $\mathrm{Zn}$ are essential elements for crops and are inclined to be translocated to the rice shoots, thus showing higher rates in the aerial part. $\mathrm{Cd}$ and $\mathrm{Pb}$ are not only non-essential but also toxic to crops and thus are mostly trapped in the crop roots.

$\mathrm{Cu}$ and $\mathrm{Zn}$ contents in the different tissues of rice plants are in the decreasing order of roots $>$ grains $>$ stems $>$ leaves and $\mathrm{Pb}$ and $\mathrm{Cd}$ in the decreasing order of roots $>$ stems $>$ leaves $>$ grains, which are consistent with many previous studies $[23,61]$. $\mathrm{Cu}$ and $\mathrm{Zn}$ are mostly accumulated in the roots, reduced in the stems and leaves, and again raised in the rice grains. This indicates that both $\mathrm{Cu}$ and $\mathrm{Zn}$, as nutrient elements, can be actively taken up by rice seeds, while $\mathrm{Pb}$ and $\mathrm{Cd}$ are mainly retained in the rice roots and stems (Figure 9). Only a small amount of $\mathrm{Pb}$ is translocated into rice grains, and a relatively higher amount of $\mathrm{Cd}$ is translocated into rice grains (Figure 9), which coincides with many previous studies $[62,63]$. Cd content in the roots and brown rice of PM on the fourth year attains $1.48 \mathrm{mg} / \mathrm{kg}$ and $0.066 \mathrm{mg} / \mathrm{kg}$, and $\mathrm{Pb}$ content $9.33 \mathrm{mg} / \mathrm{kg}$ and $0.078 \mathrm{mg} / \mathrm{kg}$, respectively. The ratio of $\mathrm{Cd}$ content in the roots, stems, leaves, and brown rice is 24:16:2:1, compared with that of $\mathrm{Pb}$ being 152: 12: 2: 1 . This also suggests that $\mathrm{Pb}$ is mostly retained in the roots, and $\mathrm{Cd}$ is relatively easily translocated into the rice grain.

\subsection{Risk of Heavy Metal Contamination in Rice Grain Caused by Application of PM and FCR}

The contents of $\mathrm{Cu}, \mathrm{Zn}, \mathrm{Pb}$ and $\mathrm{Cd}$ in the brown rice of the fertilizer treatments in each experimental year are positively correlated with those in the soils $(\mathrm{r}=0.836,0.745$, $0.874,0.949 ; n=12 ; p<0.01)$ and rice roots $(\mathrm{r}=0.843,0.930,0.926,0.968, n=12 ; p<0.01)$. The contents of $\mathrm{Cu}$ and $\mathrm{Zn}$ in the brown rice of $\mathrm{PM}, \mathrm{FV}$, and $\mathrm{AB}$ in the latter two years are significantly higher than CK $(p<0.05)$ (Figure 8). Moreover, $\mathrm{Cu}$ content in the brown rice of $\mathrm{PM}, \mathrm{FV}$, and $\mathrm{AB}$ in the latter two years is significantly higher than that in the first two years $(p<0.05)$. Pb content in the brown rice of PM, AB, and FV in the fourth year is significantly higher than $\mathrm{CK}(p<0.05)$, and $\mathrm{Cd}$ content in the brown rice of PM and FV in the four years is significantly higher than CK $(p<0.05)$. Likewise, the contents of $\mathrm{Cu}, \mathrm{Zn}, \mathrm{Pb}$, and $\mathrm{Cd}$ in the brown rice of $\mathrm{AB}$ and FV are much lower than those of PM. Heavy metals in the brown rice of the PM treatment are annually raised more significantly than those of $\mathrm{AB}$ and $\mathrm{FV}$ $(p<0.05)$ (Figure 8). For example, Cu content in the brown rice of PM attains $2.94 \mathrm{mg} / \mathrm{kg}$ in the fourth year, which is 2.0,1.1, and 1.2 times that of $C K, A B$, and FV, respectively. This also suggests that the application of PM and FCR has already posed a risk of heavy metal accumulation in brown rice, and the risk caused by the application of PM is much higher.

A root/rice ratio of $\mathrm{Cd}$ content in the $\mathrm{PM}$ rice plants is 22.1, and that of $\mathrm{Pb}$ is 119.7 , suggesting that $\mathrm{Cd}$ is more easily translocated into the rice grains and $\mathrm{Pb}$ is mostly retained in the rice roots, which is consistent with many previous studies [64-66]. It was also reported that $10 \%$ of rice samples randomly collected in the market in China exceed the safe limit of $\mathrm{Cd}$ content $(\mathrm{Cd} \leq 0.2 \mathrm{mg} / \mathrm{kg}$ ) specified by the China national standards [67]. $\mathrm{Cd}$ accumulation in soil has posed a threat to human health through the food chain $[68,69]$.

The contents of heavy metals in the brown rice of the treatments for the consecutive four years are still below the safe limits, specified by the China national standards (GB 2762-2017, NY861-2004) [70,71]. Zn in rice grains inhibits the further uptake of Cd by grains to protect itself from toxicity $[72,73]$. The high contents of $\mathrm{Cu}$ and $\mathrm{Zn}$ in rice grains reduce the mobility of $\mathrm{Pb}$ and $\mathrm{Cd}$ in rice plants [74]. 
However, $\mathrm{Cu}$ content in the brown rice of $\mathrm{PM}$ increases by $35.5 \%, 16.7 \%$, and $12.7 \%$ annually from 2018 to 2020; $\mathrm{Zn}$ increases by $15.7 \%, 11.5 \%$, and $39.2 \%$; Pb increases by $4.4 \%$, $18.8 \%$ and $141.9 \%$; $C d$ increase by $48.0 \%, 21.3 \%$, and $12.0 \%$, respectively (Figure 10 ). The amount of annual increase in $\mathrm{Cu}, \mathrm{Zn}, \mathrm{Pb}$, and $\mathrm{Cd}$ in the brown rice of $\mathrm{PM}$ is $0.43,4.56$, 0.019 , and $0.011 \mathrm{mg} / \mathrm{kg}$ on average, respectively. If continuously increasing at the rates, the contents of $\mathrm{Cu}, \mathrm{Zn}, \mathrm{Pb}$, and $\mathrm{Cd}$ in the rice grains will exceed the safe limits (NY861-2004, $\mathrm{Cu} \leq 10 \mathrm{mg} / \mathrm{kg} ; \mathrm{Zn} \leq 50 \mathrm{mg} / \mathrm{kg} ; \mathrm{Pb} \leq 0.40 \mathrm{mg} / \mathrm{kg} ; \mathrm{Cd} \leq 0.20 \mathrm{mg} / \mathrm{kg}$ ) [71] after 20, 8, 21 and 16 years of the application of pig manure, respectively. Long-term application of PM to paddy fields raises the risk of $\mathrm{Cd}$ contamination of rice [75]. The risk of heavy metal accumulation in rice grains by long-term application of PM and FCR, therefore, can never be neglected.

The bioaccumulation coefficients (BAC) in rice, brown rice/soils ratios of heavy metals were calculated. $\mathrm{Cd}$ is much mobile in grain plants and can be actively taken up by grain [76-78]. The BAC of $\mathrm{Cd}$ in the rice grains is the highest (Figure 11). $\mathrm{Cu}$ and $\mathrm{Zn}$ are two essential elements for plants and can also be easily taken up and transferred to rice grain. Thus, the BAC of $\mathrm{Cu}$ and $\mathrm{Zn}$ in the grains is also high. $\mathrm{Pb}$ is mostly retained in the roots, and its BAC is the lowest. The BAC of heavy metals for the AB, FV, and PM treatments are mostly significantly higher than $C K(p<0.05)$, suggesting that the applications of PM and FCR increase the risk of heavy metal accumulation in rice grains. Moreover, the BAC of $\mathrm{Pb}$ in the $\mathrm{PM}$ grains is significantly higher than that in $\mathrm{CK}, \mathrm{AB}$, and $\mathrm{FV}(p<0.05)$, the $\mathrm{BAC}$ of $\mathrm{Zn}$ in the PM and FV grains significantly higher than that in $\mathrm{CK}$ and $\mathrm{AB}$, and the BAC of Cd in the PM and AB grains significantly higher than that in CK and FV $(p<0.05)$, further suggesting that the application of PM more easily leads to the accumulation of heavy metals in rice grains.
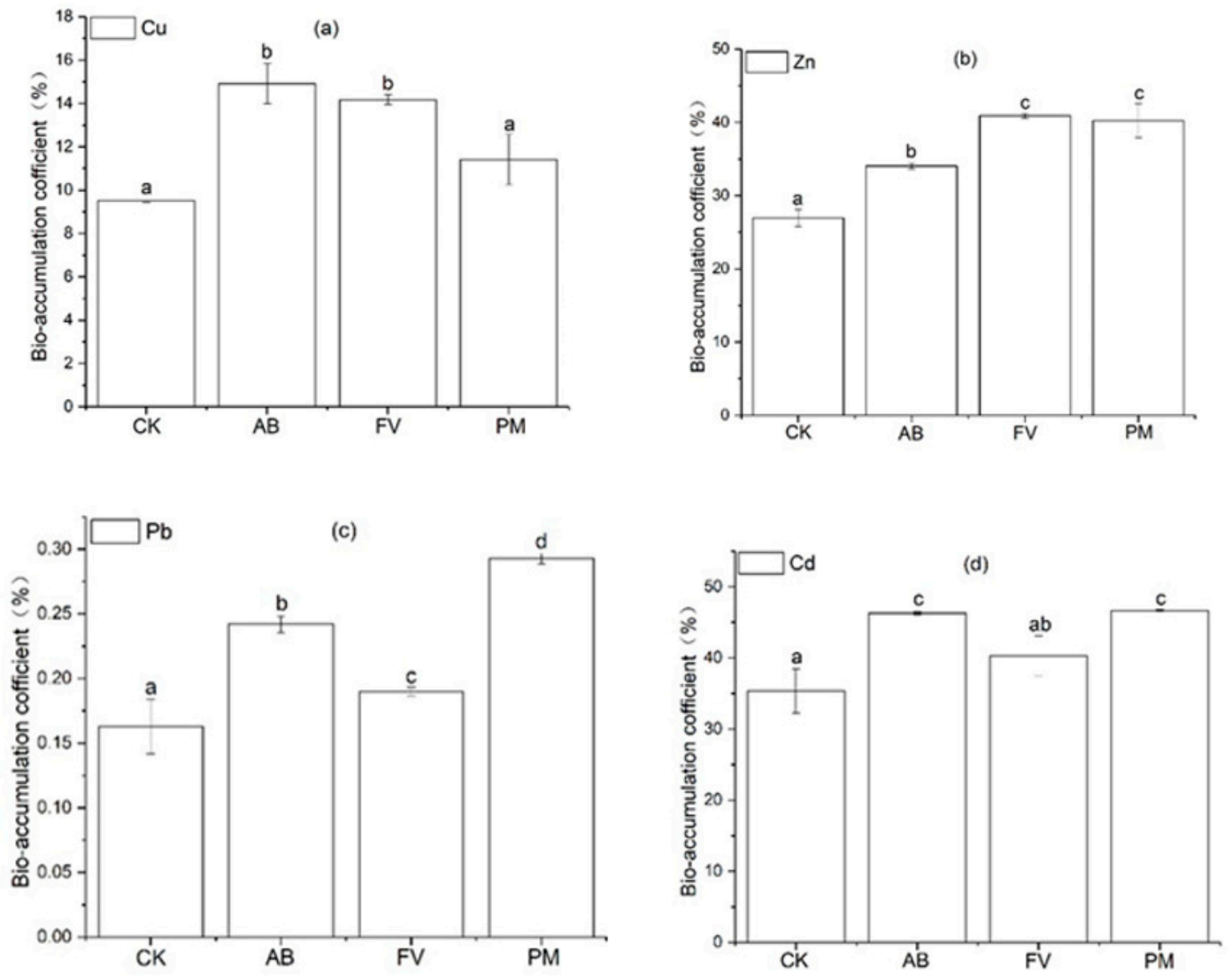

Figure 11. (a) BAC of $\mathrm{Cu}$ in the brown rice of the different treatments; (b) BAC of $\mathrm{Zn}$ in the brown rice of the different treatments; (c) BAC of $\mathrm{Pb}$ in the brown rice of the different treatments; (d) BAC of $\mathrm{Cd}$ in the brown rice of the different treatments. Data are expressed as means $\pm \mathrm{SD} ; n=3$. Different letters on data in the same group indicate a significant difference between them at $p<0.05$ level. 


\section{Materials and Methods}

\subsection{Study Area}

Located in front of the Yangtze River Delta, Shanghai is surrounded by water on three sides. The land area of Shanghai was initially created by the combined action of the Yangtze River and the East China Sea, with an elevation of $3.2 \mathrm{~m}$ on average. Shanghai has a subtropical humid monsoon climate with a mean annual temperature of $17.1^{\circ} \mathrm{C}$ and a mean annual rainfall of $1223.4 \mathrm{~mm}$. An experimental field is situated at Professor's Farm (31 $07^{\prime} \mathrm{N}, 12053^{\prime} \mathrm{E}$ ) of Qingpu District in the western suburb of Shanghai. The soils in the experimental site are mostly derived from the sediments of lakes and rivers, with clayey loam texture, and are mostly classified as entisols. Some physical-chemical properties of the experimental soil are indicated in Table 2.

Table 2. Background values of nutrients in the experimental soil in the suburb of Shanghai, Southeast China. Data are means $\pm \mathrm{SD}, n=3$.

\begin{tabular}{cccccccc}
\hline $\mathrm{pH}$ & OM $(\mathrm{g} / \mathrm{kg})$ & TN $(\mathrm{g} / \mathrm{kg})$ & TP $(\mathrm{g} / \mathrm{kg})$ & TK $(\mathrm{g} / \mathrm{kg})$ & AN $(\mathrm{g} / \mathrm{kg})$ & AP $(\mathrm{g} / \mathrm{kg})$ & AK $(\mathrm{g} / \mathrm{kg})$ \\
\hline $5.20 \pm 0.12$ & $31.07 \pm 0.28$ & $1.41 \pm 0.21$ & $0.14 \pm 0.02$ & $17.91 \pm 0.48$ & $0.11 \pm 0.005$ & $0.006 \pm 0.0004$ & $0.044 \pm 0.006$ \\
\hline
\end{tabular}

\subsection{Field Experiment}

Field experiments were carried out for four consecutive years from 2017 to 2020. In each experimental year, the same four fertilizer treatments were arranged, which included the applications of PM, residues of $\mathrm{AB}$ and FV as well as non-fertilizer control (CK). Each treatment is triplicated, and the number of experimental plots is 12 in total, with each plot being $2.5 \mathrm{~m} \times 10 \mathrm{~m}$ in area and an interval of $50 \mathrm{~cm}$ between the two plots.

Rice seedlings were cultivated on seedbed in late May and then transplanted to the experimental fields in middle June. Rice grains were harvested in late October. The whole period of rice growth in the experimental years is about 120 days. A local variety of rice, Jiahe 218, suitable to the climate in Shanghai, was selected for the experiment.

PM, taken from a local pig farm, was composted for several months before being applied to the plots as an experimental treatment. Likewise, the composed culturing residues of $\mathrm{AB}$ and $\mathrm{FV}$ fetched from the two companies of edible fungi production were also applied as experimental treatments. The culture medium of FV is originally composed of corncob, hull of cottonseeds, rice bran, and husk of wheat, and that of AB composed of straw, chicken manure, rapeseed cake, hull of cottonseeds, and soybean pulp. The contents of nutrients and heavy metals in the two FCR are indicated in Table 1.

Each experimental treatment included basal and topdressing fertilizations, which were applied before seedling transplanting in early June, and during seedling jointing in early July, respectively. The amount of fertilizer application for each treatment is calculated based on the equivalent $\mathrm{N}$ content applied by conventional rice farming during the whole rice-growing season, as shown in Table 3.

Table 3. Quantities of base fertilizer and topdressing to the rice of the field experiment.

\begin{tabular}{|c|c|c|c|c|c|c|c|c|c|}
\hline \multirow[b]{2}{*}{ Treatment } & \multicolumn{4}{|c|}{ Base Fertilizer (June 2017-June 2020) } & & \multicolumn{4}{|c|}{ Topdressing (July 2017-July 2020) } \\
\hline & $\begin{array}{c}\text { Fertilization Amount } \\
\left(\mathrm{kg} / \mathrm{m}^{2}\right)\end{array}$ & TN $\left(\mathrm{g} / \mathrm{m}^{-2}\right)$ & $\underset{\left(\mathrm{g} / \mathrm{m}^{2}\right)}{\mathrm{TP}}$ & $\underset{\left(\mathrm{g} / \mathrm{m}^{2}\right)}{\mathrm{TK}}$ & & $\begin{array}{c}\text { Fertilization Amount } \\
\left(\mathrm{kg} / \mathrm{m}^{2}\right)\end{array}$ & $\underset{\left(\mathrm{g} / \mathrm{m}^{2}\right)}{\mathrm{TN}}$ & $\underset{\left(g / m^{2}\right)}{T P}$ & $\underset{\left(\mathrm{g} / \mathrm{m}^{2}\right)}{\mathrm{TK}}$ \\
\hline CK & 0.00 & 0.00 & 0.00 & 0.00 & $\mathrm{CK}$ & 0.00 & 0.00 & 0.00 & 0.00 \\
\hline $\mathrm{AB}$ & 1.33 & 9.50 & 2.15 & 0.65 & $\mathrm{AB}$ & 3.80 & 27.6 & 10.88 & 5.84 \\
\hline FV & 0.57 & 9.50 & 3.36 & 1.14 & FV & 4.04 & 27.6 & 13.75 & 4.91 \\
\hline PM & 0.48 & 9.50 & 5.52 & 1.15 & PM & 1.21 & 27.6 & 16.99 & 3.03 \\
\hline
\end{tabular}

\subsection{Investigation and Sampling}

The growth of rice plants was investigated each week during the whole rice-growing season. The rice grains of each plot were harvested and weighed independently to calculate the actual yield of rice grains. 
Six rice plants in each plot were randomly collected in each experimental plot after it was matured. The plant samples were immediately carried to the laboratory, cleaned with deionized water, and divided into the subsamples of roots, stems, leaves, and rice grains, which were oven-dried at $90{ }^{\circ} \mathrm{C}$ for $30 \mathrm{~min}$ and then continuously dried at $70{ }^{\circ} \mathrm{C}$ for $12 \mathrm{~h}$. The dried plant samples were ground into powder for chemical analyses.

The cultivated layers of the soils $(0-20 \mathrm{~cm})$ in each plot were sampled in the different periods of the rice-growing season. The samples were crushed, ground, and then passed through $2 \mathrm{~mm}$ - and $0.149 \mathrm{~mm}$-sized nylon sieves successively for chemical analyses.

\subsection{Sample Analyses}

The content of $\mathrm{OM}$ in the soils was determined by the potassium dichromate-sulfuric acid method; TN by the Kjeldahl method; AN by the alkaline diffusion method; TP by the acid digestion-phosphomolybdate colorimetric method; AP by the $\mathrm{NaHCO}_{3}$ solution extraction-phosphomolybdate colorimetric method; TK content by the acid dissolution method; AK by ammonium acetate extraction method [79].

$0.2 \mathrm{~g}$ soil sample $(<0.149 \mathrm{~mm})$ was put into Teflon crucible and digested with the three mixed acids $\left(\mathrm{HNO}_{3}-\mathrm{HClO}_{4}-\mathrm{HF}\right)$. All the reagents are guaranteed. The contents of $\mathrm{Cu}$ and $\mathrm{Zn}$ in the solution were determined by the inductively coupled plasma-atomic emission spectrometry (ICP-AES, Mason, OH, USA) of Leeman Prodigy produced by American Leeman Instrument Co. Ltd., with the error being $1.52-3.43 \%$, and the relative standard deviation being less than $3 \%$. The minimum detection limits for $\mathrm{Cu}$ and $\mathrm{Zn}$ are $0.002 \mu \mathrm{g} / \mathrm{mL}$. The contents of $\mathrm{Cd}$ and $\mathrm{Pb}$ were determined by the graphite furnace atomic absorption spectrophotometer (GF-AAS, Jena, Germany) (Zee nit 600/650) produced by Jena Company, Germany, with the error being $2.31-4.13 \%$ and the relative standard deviation being less than $5 \%$. The minimum detection limits for $\mathrm{Pb}$ and $\mathrm{Cd}$ are $0.06 \mu \mathrm{g} / \mathrm{L}$ and $0.008 \mu \mathrm{g} / \mathrm{L}$.

The samples of rice plants, PM, and FCR were put into beakers and digested with the mixed acids $\left(\mathrm{HNO}_{3}+\mathrm{HCl}+\mathrm{HClO}_{4}\right)$. The contents of $\mathrm{Cu}, \mathrm{Zn}, \mathrm{Cd}$, and $\mathrm{Pb}$ in the solution were determined by the GF-AAS.

The bioavailability of heavy metals in soils was evaluated by BAC. The BAC (\%) of a heavy metal element in rice grains reflects the transfer and bioaccumulation of the element from soil to grain [80].

$$
\operatorname{BAC}(\%)=\frac{C_{\text {rice }}}{C_{x}} \times 100
$$

$\mathrm{C}_{\text {rice: }}$ Heavy metal content in rice grains; $\mathrm{C}_{\mathrm{x}}$ : heavy metal content in soil.

\subsection{Statistical Analysis}

All the experimental data were firstly treated by Microsoft Excel 2016 (Microsoft, Redmond, WA, USA). The data were commonly expressed as the mean \pm standard deviation (SD), and the statistical difference was checked by the Duncan test, with the significance level set to $p<0.05$. The significances of differences among the data and Pearson correlations between the two groups of data were analyzed by IBM SPSS Statistics 24.0 (IBM, New York, NY, USA). All the graphs were drawn using Origin 9.1 (OriginLab, Northampton, MA, USA).

\section{Conclusions}

The applications of PM and FCR to the paddy fields raise the contents of OM and nutrients in the soils significantly and increase grain yield effectively. However, both lead to an annual accumulative increase in heavy metals in the soils. Especially, the risk of heavy metal accumulation by the application of PM is more significant. $\mathrm{Cu}$ and $\mathrm{Zn}$ contents in the soil of the $\mathrm{PM}$ treatment are significantly raised during the four years, and $\mathrm{Pb}$ and $\mathrm{Cd}$ are also significantly raised in the latter two years.

Heavy metals in the rice plants by the application of PM and FCR also increase annually. These taken up by plants are mostly retained in the roots. $\mathrm{Cu}$ and $\mathrm{Zn}$ contents in the rice roots of PM are significantly higher than CK during the four experimental years, 
and $\mathrm{Pb}$ and $\mathrm{Cd}$ are also significantly higher than $\mathrm{CK}$ in the latter two years. $\mathrm{Cu}$ and $\mathrm{Zn}$ contents in the rice plants are in the decreasing order of roots $>$ rice grains $>$ stems $>$ leaves, and $\mathrm{Pb}$ and $\mathrm{Cd}$ in the decreasing order of roots $>$ stems $>$ leaves $>$ rice grains.

The contents of $\mathrm{Cu}, \mathrm{Zn}, \mathrm{Pb}$, and $\mathrm{Cd}$ in the brown rice by the $\mathrm{PM}, \mathrm{FV}$, and $\mathrm{AB}$ treatments increase annually, which are positively significantly correlated with those in the soils and rice roots $(p<0.05)$. This suggests that the heavy metals accumulated in the brown rice are caused by the applications of PM and FCR. The risk of heavy metals by the application of $\mathrm{PM}$ is even more significant. Though the contents of heavy metals in the brown rice are still within the safe levels during the experimental years, the risks of their accumulative increments, especially by long-term application of PM, can never be neglected.

Author Contributions: Conceptualization, X.H. and C.Y.; methodology, F.L. and J.L.; investigation, S.L.; X.W. and Z.J.; data curation, W.L.; writing—original draft preparation, W.L.; writing-review and editing, X.H.; funding acquisition, C.Y. All authors have read and agreed to the published version of the manuscript.

Funding: The authors acknowledge financial support from the Shanghai Agriculture Applied Technology Development Program, Shanghai Agricultural Commission, China (grant no. G20190301), the National Natural Science Foundation of China (no. 40877005), and the project from Shanghai Science and Technology Commission (grant no. 20392002200).

Institutional Review Board Statement: Not applicable.

Informed Consent Statement: Not applicable.

Data Availability Statement: All data are provided in the manuscript.

Conflicts of Interest: The authors declare no conflict of interest.

\section{References}

1. Uphoff, N.; Dazzo, F.B. Making Rice Production More Environmentally-Friendly. Environments 2016, 3, 12. [CrossRef]

2. Qian, X.; Wang, Z.; Shen, G.; Chen, X.; Tang, Z.; Guo, C.; Gu, H.; Fu, K. Heavy metals accumulation in soil after 4 years of continuous land application of swine manure: A field-scale monitoring and modeling estimation. Chemosphere 2018, 210, 1029-1034. [CrossRef]

3. Onwosi, C.O.; Igbokwe, V.C.; Odimba, J.N.; Eke, I.E.; Nwankwoala, M.O.; Iroh, I.N.; Ezeogu, L.I. Composting technology in waste stabilization: On the methods, challenges and future prospects. J. Environ. Manag. 2017, 190, 140-157. [CrossRef]

4. Cai, A.; Xu, M.; Wang, B.; Zhang, W.; Liang, G.; Hou, E.; Luo, Y. Manure acts as a better fertilizer for increasing crop yields than synthetic fertilizer does by improving soil fertility. Soil Tillage Res. 2019, 189, 168-175. [CrossRef]

5. Stroppa, N.; Onelli, E.; Hejna, M.; Rossi, L.; Gagliardi, A.; Bini, L.; Baldi, A.; Moscatelli, A. Typha latifolia and Thelypteris palustris behavior in a pilot system for the refinement of livestock wastewaters: A case of study. Chemosphere 2020, 240, 14. [CrossRef]

6. Jin, H.; Chang, Z. Distribution of heavy metal contents and chemical fractions in anaerobically digested manure slurry. Appl. Biochem. Biotechnol. 2011, 164, 268-282. [CrossRef]

7. Huang, H.; Li, B.; Li, J.; Zhang, P.; Yu, W.; Zhao, N.; Guo, G.; Young, B. Influence of process parameters on the heavy metal $(\mathrm{Zn}(2+), \mathrm{Cu}(2+)$ and $\mathrm{Cr}(3+))$ content of struvite obtained from synthetic swine wastewater. Environ. Pollut. 2019, 245, 658-665. [CrossRef] [PubMed]

8. Mu, H.Y.; Zhuang, Z.; Li, Y.M.; Qiao, Y.H.; Chen, Q.; Xiong, J.; Guo, L.L.; Jiang, R.F.; Li, H.-F. Heavy Metal Contents in Animal Manure in China and the Related Soil Accumulation Risks. Huan Jing Ke Xue 2020, 41, 986-996. [CrossRef] [PubMed]

9. Franco, A.; Schuhmacher, M.; Roca, E.; Luis, D.J. Application of cattle manure as fertilizer in pastureland: Estimating the incremental risk due to metal accumulation employing a multicompartment model. Environ. Int. 2006, 32, 724-732. [CrossRef] [PubMed]

10. Yang, X.; Li, Q.; Tang, Z.; Zhang, W.; Yu, G.; Shen, Q.; Zhao, F.J. Heavy metal concentrations and arsenic speciation in animal manure composts in China. Waste Manag. 2017, 64, 333-339. [CrossRef] [PubMed]

11. Sager, M. Trace and nutrient elements in manure, dung and compost samples in Austria. Soil Biol. Biochem. 2007, 39, 1383-1390. [CrossRef]

12. Shi, J.; Yu, X.; Zhang, M.; Lu, S.; Wu, W.; Wu, J.; Xu, J. Potential Risks of Copper, Zinc, and Cadmium Pollution due to Pig Manure Application in a Soil-Rice System under Intensive Farming: A Case Study of Nanhu, China. J. Environ. Qual. 2011, 40, 1695-1704. [CrossRef] [PubMed]

13. Zhang, F.; Li, Y.; Yang, M.; Li, W. Content of Heavy Metals in Animal Feeds and Manures from Farms of Different Scales in Northeast China. Int. J. Environ. Res. Public Health 2012, 9, 2658-2668. [CrossRef] 
14. Xu, Y.; Yu, W.; Ma, Q.; Zhou, H. Accumulation of copper and zinc in soil and plant within ten-year application of different pig manure rates. Plant. Soil Environ. 2013, 59, 492-499. [CrossRef]

15. Zhao, Y.; Yan, Z.; Qin, J.; Xiao, Z. Effects of long-term cattle manure application on soil properties and soil heavy metals in corn seed production in Northwest China. Environ. Sci. Pollut. Res. 2014, 21, 7586-7595. [CrossRef] [PubMed]

16. Liang, X.; Jin, Y.; He, M.; Liu, Y.; Hua, G.; Wang, S.; Tian, G. Composition of phosphorus species and phosphatase activities in a paddy soil treated with manure at varying rates. Agric. Ecosyst. Environ. 2017, 237, 173-180. [CrossRef]

17. Liang, Y.G.; Li, X.J.; Zhang, J.; Zhang, L.G.; Cheng, B. Effect of microscale ZVI/magnetite on methane production and bioavailability of heavy metals during anaerobic digestion of diluted pig manure. Environ. Sci. Pollut. Res. 2017, 24, 12328-12337. [CrossRef]

18. Cang, L.; Wang, Y.J.; Zhou, D.M.; Dong, Y.H. Heavy metals pollution in poultry and livestock feeds and manures under intensive farming in Jiangsu Province, China. J. Environ. Sci. 2004, 16, 371-374.

19. Peng, S.; Wang, Y.; Zhou, B.; Lin, X. Long-term application of fresh and composted manure increase tetracycline resistance in the arable soil of eastern China. Sci. Total Environ. 2015, 506-507, 279-286. [CrossRef]

20. Meng, J.; Liang, S.; Tao, M.; Liu, X.; Brookes, P.C.; Xu, J. Chemical speciation and risk assessment of Cu and Zn in biochars derived from co-pyrolysis of pig manure with rice straw. Chemosphere 2018, 200, 344-350. [CrossRef]

21. Muthayya, S.; Sugimoto, J.D.; Montgomery, S.; Maberly, G.F. An overview of global rice production, supply, trade, and consumption. Ann. N. Y. Acad. Sci. 2014, 1324, 7-14. [CrossRef] [PubMed]

22. Gu, J.F.; Zhou, H.; Tang, H.L.; Yang, W.T.; Zeng, M.; Liu, Z.M.; Peng, P.Q.; Liao, B.H. Cadmium and arsenic accumulation during the rice growth period under in situ remediation. Ecotoxicol. Environ. Saf. 2019, 171, 451-459. [CrossRef]

23. Zhou, H.; Zhu, W.; Yang, W.T.; Gu, J.F.; Gao, Z.X.; Chen, L.W.; Du, W.Q.; Zhang, P.; Peng, P.Q.; Liao, B.H. Cadmium uptake, accumulation, and remobilization in iron plaque and rice tissues at different growth stages. Ecotoxicol. Environ. Saf. 2018, 152, 91-97. [CrossRef] [PubMed]

24. Shan, H.; Su, S.; Liu, R.; Li, S. Cadmium availability and uptake by radish (Raphanus sativus) grown in soils applied with wheat straw or composted pig manure. Environ. Sci. Pollut. Res. 2016, 23, 15208-15217. [CrossRef]

25. Qian, X.; Shen, G.; Wang, Z.; Zhang, X.; Hong, Z. Effect of swine liquid manure application in paddy field on water quality, soil fertility and crop yields. Paddy Water Environ. 2018, 16, 15-22. [CrossRef]

26. Demelash, N.; Bayu, W.; Tesfaye, S.; Ziadat, F.; Sommer, R. Current and residual effects of compost and inorganic fertilizer on wheat and soil chemical properties. Nutr. Cycl. Agroecosyst. 2014, 100, 357-367. [CrossRef]

27. Carpenter, S.R.; Caraco, N.F.; Correll, D.L.; Howarth, R.W.; Sharpley, A.N.; Smith, V.H. Nonpoint pollution of surface waters with phosphorus and nitrogen. Ecol. Appl. 1998, 8, 559-568. [CrossRef]

28. Li, F.; Li, Z.; Mao, P.; Li, Y.; Li, Y.; McBride, M.B.; Wu, J.; Zhuang, P. Heavy metal availability, bioaccessibility, and leachability in contaminated soil: Effects of pig manure and earthworms. Environ. Sci. Pollut. Res. 2019, 26, 20030-20039. [CrossRef]

29. Antonious, G.F.; Kochhar, T.S.; Coolong, T. Yield, quality, and concentration of seven heavy metals in cabbage and broccoli grown in sewage sludge and chicken manure amended soil. J. Environ. Sci. Health Part A-Toxic/Hazard. Subst. Environ. Eng. 2012, 47, 1955-1965. [CrossRef]

30. Liu, D.Y.; Zhang, W.; Pang, L.L.; Zhang, Y.Q.; Wang, X.Z.; Liu, Y.M.; Chen, X.P.; Zhang, F.S.; Zou, C.Q. Effects of zinc application rate and zinc distribution relative to root distribution on grain yield and grain Zn concentration in wheat. Plant Soil 2017, 411, 167-178. [CrossRef]

31. Liu, D.Y.; Zhang, W.; Yan, P.; Chen, X.P.; Zhang, F.S.; Zou, C.Q. Soil application of zinc fertilizer could achieve high yield and high grain zinc concentration in maize. Plant Soil 2017, 411, 47-55. [CrossRef]

32. Wei, W.; Yan, Y.; Cao, J.; Christie, P.; Zhang, F.; Fan, M. Effects of combined application of organic amendments and fertilizers on crop yield and soil organic matter: An integrated analysis of long-term experiments. Agric. Ecosyst. Environ. 2016, 225, 86-92. [CrossRef]

33. Hu, N.; Wang, B.; Gu, Z.; Tao, B.; Zhang, Z.; Hu, S.; Zhu, L.; Meng, Y. Effects of different straw returning modes on greenhouse gas emissions and crop yields in a rice-wheat rotation system. Agric. Ecosyst. Environ. 2016, 223, 115-122. [CrossRef]

34. Zhang, L.; Zheng, J.; Chen, L.; Shen, M.; Zhang, X.; Zhang, M.; Bian, X.; Zhang, J.; Zhang, W. Integrative effects of soil tillage and straw management on crop yields and greenhouse gas emissions in a rice-wheat cropping system. Eur. J. Agron. 2015, 63, 47-54. [CrossRef]

35. Irshad, M.; Malik, A.H.; Shaukat, S.; Mushtaq, S.; Ashraf, M. Characterization of Heavy Metals in Livestock Manures. Pol. J. Environ. Stud. 2013, 22, 1257-1262.

36. Li, Y.X.; Li, W.; Wu, J.; Xu, L.C.; Su, Q.H.; Xiong, X. Contribution of additives $\mathrm{Cu}$ to its accumulationin pig feces: Study in Beijing and Fuxin of China. J. Environ. Sci. 2007, 19, 610-615. [CrossRef]

37. Dach, J.; Starmans, D. Heavy metals balance in Polish and Dutch agronomy: Actual state and previsions for the future. Agric. Ecosyst. Environ. 2005, 107, 309-316. [CrossRef]

38. Tan, C.Y.; Wu, L.H.; Luo, Y.M.; Xu, J.M.; Han, X.Z.; Qiao, Y.F. Cadmium accumulation and its development tendency in black soil under long-term fertilization. J. Appl. Ecol. 2008, 19, 2738-2744.

39. Karami, M.; Amini, M.; Afyuni, M.; Khoshgoftarmanesh, A.H.; Keller, A.; Abdi, A.; Schulin, R. Agricultural zinc fluxes into soils and crops of central Iran at regional scale. Arch. Agron. Soil Sci. 2014, 60, 437-456. [CrossRef] 
40. McBride, M.B.; Spiers, G. Trace element content of selected fertilizers and dairy manures as determined by ICP-MS. Commun. Soil Sci. Plant Anal. 2001, 32, 139-156. [CrossRef]

41. Luo, L.; Ma, Y.; Zhang, S.; Wei, D.; Zhu, Y.G. An inventory of trace element inputs to agricultural soils in China. J. Environ. Manag. 2009, 90, 2524-2530. [CrossRef]

42. Wu, L.; Tan, C.; Liu, L.; Zhu, P.; Peng, C.; Luo, Y.; Christie, P. Cadmium bioavailability in surface soils receiving long-term applications of inorganic fertilizers and pig manure. Geoderma 2012, 173, 224-230. [CrossRef]

43. Dudka, S.; Miller, W.P. Accumulation of potentially toxic elements in plants and their transfer to human food chain. J. Environ. Sci. Health Part B Pestic. Food Contam. Agric. Wastes 1999, 34, 681-708. [CrossRef]

44. Gong, Q.; Chen, P.; Shi, R.; Gao, Y.; Zheng, S.A.; Xu, Y.; Shao, C.; Zheng, X. Health Assessment of Trace Metal Concentrations in Organic Fertilizer in Northern China. Int. J. Environ. Res. Public Health 2019, 16, 1031. [CrossRef]

45. Kirkham, M.B. Cadmium in plants on polluted soils: Effects of soil factors, hyperaccumulation, and amendments. Geoderma 2006, 137, 19-32. [CrossRef]

46. Xu, Y.G.; Yu, W.T.; Ma, Q.; Zhou, H. Potential risk of cadmium in a soil-plant system as a result of long-term (10 years) pig manure application. Plant Soil Environ. 2015, 61, 352-357. [CrossRef]

47. Guo, G.; Lei, M.; Chen, T.; Yang, J. Evaluation of different amendments and foliar fertilizer for immobilization of heavy metals in contaminated soils. J. Soils Sediments 2018, 18, 239-247. [CrossRef]

48. Wang, X.; Zheng, G.; Chen, T.; Shi, X.; Wang, Y.; Nie, E.; Liu, J. Effect of phosphate amendments on improving the fertilizer efficiency and reducing the mobility of heavy metals during sewage sludge composting. J. Environ. Manag. 2019, 235, 124-132. [CrossRef] [PubMed]

49. Guo, T.; Lou, C.; Zhai, W.; Tang, X.; Hashmi, M.Z.; Murtaza, R.; Li, Y.; Liu, X.; Xu, J. Increased occurrence of heavy metals, antibiotics and resistance genes in surface soil after long-term application of manure. Sci. Total Environ. 2018, 635, 995-1003. [CrossRef] [PubMed]

50. Basar, H. Methods for Estimating Phytoavailable Metals in Soils. Commun. Soil Sci. Plant Anal. 2009, 40, 1087-1105. [CrossRef]

51. Shaheen, S.M.; Rinklebe, J. Impact of emerging and low cost alternative amendments on the (im)mobilization and phytoavailability of $\mathrm{Cd}$ and $\mathrm{Pb}$ in a contaminated floodplain soil. Ecol. Eng. 2015, 74, 319-326. [CrossRef]

52. Halim, M.A.; Majumder, R.K.; Zaman, M.N. Paddy soil heavy metal contamination and uptake in rice plants from the adjacent area of Barapukuria coal mine, northwest Bangladesh. Arab. J. Geosci. 2015, 8, 3391-3401. [CrossRef]

53. Sprynskyy, M.; Kowalkowski, T.; Tutu, H.; Cozmuta, L.M.; Cukrowska, E.M.; Buszewski, B. The Adsorption Properties of Agricultural and Forest Soils Towards Heavy Metal Ions (Ni, Cu, Zn, and Cd). Soil Sediment Contam. 2011, 20, 12-29. [CrossRef]

54. GB NY-525-(2012) Organic Manure Standard. Available online: https://img.antpedia.com/standard/files/pdfs_ora/CN-NY/30 e/NY\%20525-2012_2500.pdf (accessed on 9 January 2022).

55. McLaughlin, M.J.; Parker, D.R.; Clarke, J.M. Metals and micronutrients-Food safety issues. Field Crops Res. 1999, 60, 143-163. [CrossRef]

56. Xiong, X.; Li, Y.; Li, W.; Lin, C.; Han, W.; Yang, M. Copper content in animal manures and potential risk of soil copper pollution with animal manure use in agriculture. Resour. Conserv. Recycl. 2010, 54, 985-990. [CrossRef]

57. Wan, Y.; Huang, Q.; Wang, Q.; Yu, Y.; Su, D.; Qiao, Y.; Li, H. Accumulation and bioavailability of heavy metals in an acid soil and their uptake by paddy rice under continuous application of chicken and swine manure. J. Hazard. Mater. 2020, 384, 121293. [CrossRef]

58. Merrington, G.; Madden, C. Changes in cadmium and zinc phytoavailability in agricultural soil after amendment with papermill sludge and biosolids. Commun. Soil Sci. Plant Anal. 2000, 31, 759-776. [CrossRef]

59. Weggler-Beaton, K.; McLaughlin, M.J.; Graham, R.D. Salinity increases cadmium uptake by wheat and Swiss chard from soil amended with biosolids. Aust. J. Soil Res. 2000, 38, 37-45. [CrossRef]

60. GB 15618-(2018). Environmental Quality Standards for Soils. Part 7.2: Level 2 of Environmental Quality Standards for Soil Inorganic Matter. Available online: https://img.antpedia.com/standard/files/pdfs_ora/20200926/GB\%2015618-2018.pdf (accessed on 9 January 2022).

61. Ochoa, M.; Tierra, W.; Santiago Tupuna-Yerovi, D.; Guanoluisa, D.; Luis Otero, X.; Ruales, J. Assessment of cadmium and lead contamination in rice farming soils and rice (Oryza sativa L.) from Guayas province in Ecuador. Environ. Pollut. 2020, 260, 114050. [CrossRef]

62. Bingham, F.T. Bioavailability of Cd to Food crops in relation to heavy metal content of sludge-amended soil. Environ. Health Perspect. 1979, 28, 39-43. [CrossRef]

63. Song, W.E.; Chen, S.B.; Liu, J.F.; Chen, L.; Song, N.N.; Li, N.; Liu, B. Variation of Cd concentration in various rice cultivars and derivation of cadmium toxicity thresholds for paddy soil by species-sensitivity distribution. J. Integr. Agric. 2015, 14, 1845-1854. [CrossRef]

64. Harris, N.S.; Taylor, G.J. Cadmium uptake and partitioning in durum wheat during grain filling. BMC Plant Biol. 2013, 13, 103. [CrossRef] [PubMed]

65. Yoneyama, T.; Gosho, T.; Kato, M.; Goto, S.; Hayashi, H. Xylem and phloem transport of Cd, Zn and Fe into the grains of rice plants (Oryza sativa L.) grown in continuously flooded Cd-contaminated soil. Soil Sci. Plant Nutr. 2010, 56, 445-453. [CrossRef]

66. Ashraf, U.; Kanu, A.S.; Deng, Q.; Mo, Z.; Pan, S.; Tian, H.; Tang, X. Lead (Pb) Toxicity; Physio-Biochemical Mechanisms, Grain Yield, Quality, and Pb Distribution Proportions in Scented Rice. Front. Plant Sci. 2017, 8, 259. [CrossRef] 
67. Chen, H.; Tang, Z.; Wang, P.; Zhao, F.J. Geographical variations of cadmium and arsenic concentrations and arsenic speciation in Chinese rice. Environ. Pollut. 2018, 238, 482-490. [CrossRef]

68. Jarup, L.; Akesson, A. Current status of cadmium as an environmental health problem. Toxicol. Appl. 2009, 238, 201-208. [CrossRef]

69. Chen, Z.F.; Zhao, Y.; Zhu, Y.; Yang, X.; Qiao, J.; Tian, Q.; Zhang, Q. Health risks of heavy metals in sewage-irrigated soils and edible seeds in Langfang of Hebei province, China. J. Sci. Food Agric. 2010, 90, 314-320. [CrossRef] [PubMed]

70. GB 2762-(2017). Limit of Contaminants in Food Safety of National Standards. Available online: https://kns.cnki.net/kcms/ detail / detail.aspx?FileName=ZSPZ201803030\&DbName=CJFQ2018. (accessed on 9 January 2022).

71. GB NY-861-(2004). Limit Standard for Grain and Products. Available online: https://img.antpedia.com/standard/files/pdfs_ ora/CN-NY/3f8/NY\%20861-2004.pdf (accessed on 9 January 2022).

72. Romkens, P.F.A.M.; Guo, H.Y.; Chu, C.L.; Liu, T.S.; Chiang, C.F.; Koopmans, G.F. Prediction of Cadmium uptake by brown rice and derivation of soil-plant transfer models to improve soil protection guidelines. Environ. Pollut. 2009, 157, $2435-2444$. [CrossRef]

73. Han, C.; Wu, L.; Tan, W.; Zhong, D.; Huang, Y.; Luo, Y.; Christie, P. Cadmium distribution in rice plants grown in three different soils after application of pig manure with added cadmium. Environ. Geochem. Health 2012, 34, 481-492. [CrossRef]

74. Jalil, A.; Selles, F.; Clarke, J.M. Effect of cadmium on growth and the uptake of cadmium and other elements by durum wheat. J. Plant Nutr. 1994, 17, 1839-1858. [CrossRef]

75. Wang, G.; Zhou, L. Application of Green Manure and Pig Manure to Cd-Contaminated Paddy Soil Increases the Risk of Cd Uptake by Rice and Cd Downward Migration into Groundwater: Field Micro-Plot Trials. Water Air Soil Pollut. 2017, 228, 29. [CrossRef]

76. Fei, X.; Xiao, R.; Christakos, G.; Langousis, A.; Ren, Z.; Tian, Y.; Lv, X. Comprehensive assessment and source apportionment of heavy metals in Shanghai agricultural soils with different fertility levels. Ecol. Indic. 2019, 106, 105508. [CrossRef]

77. Xiao, R.; Guo, D.; Ali, A.; Mi, S.S.; Liu, T.; Ren, C.Y.; Li, R.H.; Zhang, Z.Q. Accumulation, ecological-health risks assessment, and source apportionment of heavy metals in paddy soils: A case study in Hanzhong, Shaanxi, China. Environ. Pollut. 2019, 248, 349-357. [CrossRef] [PubMed]

78. Qaswar, M.; Liu, Y.; Huang, J.; Liu, K.; Mudasir, M.; Lv, Z.; Hou, H.; Lan, X.; Ji, J.; Ahmed, W.; et al. Soil nutrients and heavy metal availability under long-term combined application of swine manure and synthetic fertilizers in acidic paddy soil. J. Soils Sediments 2020, 20, 2093-2106. [CrossRef]

79. Zhang, G.L.; Gong, Z.T. Soil Survey Laboratory Methods; Science Press: Beijing, China, 2012; pp. 36-96.

80. Xiao, R.; Wang, S.; Li, R.; Wang, J.J.; Zhang, Z. Soil heavy metal contamination and health risks associated with artisanal gold mining in Tongguan, Shaanxi, China. Ecotoxicol. Environ. Saf. 2017, 141, 17-24. [CrossRef] [PubMed] 